\title{
S-33 constraints on the seawater sulfate contribution in modern seafloor hydrothermal vent sulfides
}

\author{
Shuhei Ono ${ }^{1, *}$, Wayne C. Shanks III ${ }^{2}$, Olivier J. Rouxel ${ }^{3}$, and Douglas Rumble ${ }^{1}$ \\ ${ }^{1}$ Geophysical Laboratory, Carnegie Institution of Washington, 5251 Broad Branch Rd. NW, \\ Washington DC, 20015, USA \\ ${ }^{2}$ U.S. Geological Survey, 973 Denver Federal Center, Denver Colorado 80255 \\ ${ }^{3}$ Marine Chemistry and Geochemistry Department, Woods Hole Oceanographic Institution, \\ MS\#25, Woods Hole, MA 02543, USA \\ A manuscript accepted in Geochimica et Cosmochimica Acta
}

*Corresponding author: Shuhei Ono, email: s.ono@gl.ciw.edu, Fax: 202-478-8901

Running head: S-33 constraints on the seafloor hydrothermal vent sulfides

Index terms: sulfur isotope, multiple-isotope, mass-dependent, S-33, S-36, sulfur cycle, hydrothermal, vent, mass-independent, isotope fractionation 


\begin{abstract}
Sulfide sulfur in mid-oceanic ridge hydrothermal vents is derived from leaching of basaltic-sulfide and seawater-derived sulfate that is reduced during high temperature water rock interaction. Conventional sulfur isotope studies, however, are inconclusive about the massbalance between the two sources because ${ }^{34} \mathrm{~S} /{ }^{32} \mathrm{~S}$ ratios of vent fluid $\mathrm{H}_{2} \mathrm{~S}$ and chimney sulfide minerals may reflect not only the mixing ratio but also isotope exchange between sulfate and sulfide. Here, we show that high-precision analysis of S-33 can provide a unique constraint because isotope mixing and isotope exchange result in different $\Delta^{33} \mathrm{~S}\left(\equiv \delta^{33} \mathrm{~S}-0.515 \delta^{34} \mathrm{~S}\right)$ values of up to $0.04 \%$ even if $\delta^{34} \mathrm{~S}$ values are identical. Detection of such small $\Delta^{33} \mathrm{~S}$ differences is technically feasible by using the $\mathrm{SF}_{6}$ dual-inlet mass-spectrometry protocol that has been improved to achieve a precision as good as $0.006 \%(2 \sigma)$.

Sulfide minerals (marcasite, pyrite, chalcopyrite, and sphalerite) and vent $\mathrm{H}_{2} \mathrm{~S}$ collected from four active seafloor hydrothermal vent sites, East Pacific Rise (EPR) $9-10^{\circ} \mathrm{N}, 13^{\circ} \mathrm{N}$, and $21^{\circ} \mathrm{S}$ and Mid-Atlantic Ridge (MAR) $37^{\circ} \mathrm{N}$ yield $\Delta^{33} \mathrm{~S}$ values ranging from -0.002 to 0.033 and $\delta^{34} \mathrm{~S}$ from -0.5 to $5.3 \%$. The combined $\delta^{34} \mathrm{~S}$ and $\Delta^{33} \mathrm{~S}$ systematics reveal that 73 to $89 \%$ of vent sulfides are derived from leaching from basaltic sulfide and only 11 to $27 \%$ from seawaterderived sulfate. Pyrite from EPR $13^{\circ} \mathrm{N}$ and marcasite from MAR $37^{\circ} \mathrm{N}$ are in isotope disequilibrium not only in $\delta^{34} \mathrm{~S}$ but also in $\Delta^{33} \mathrm{~S}$ with respect to associated sphalerite and chalcopyrite, suggesting non-equilibrium sulfur isotope exchange between seawater sulfate and sulfide during pyrite precipitation. Seafloor hydrothermal vent sulfides are characterized by low $\Delta^{33} \mathrm{~S}$ values compared with biogenic sulfides, suggesting little or no contribution of sulfide from microbial sulfate reduction into hydrothermal sulfides at sediment-free mid-oceanic ridge
\end{abstract}


systems. We conclude that ${ }^{33} \mathrm{~S}$ is an effective new tracer for interplay among seawater, oceanic crust and microbes in subseafloor hydrothermal sulfur cycles. 


\section{INTRODUCTION}

Sulfur has four stable isotopes, ${ }^{32} \mathrm{~S},{ }^{33} \mathrm{~S},{ }^{34} \mathrm{~S}$ and ${ }^{36} \mathrm{~S}$. For more than half a century, however, studies of sulfur isotope geochemistry have been focused only on the measurements of ${ }^{32} \mathrm{~S}$ and ${ }^{34} \mathrm{~S}$. Additional isotopes, ${ }^{33} \mathrm{~S}$ and ${ }^{36} \mathrm{~S}$, were thought to carry no additional information because isotope fractionations by most terrestrial processes (e.g., biological, hydrothermal) follow mass-dependent fractionation laws that establish relationships among multiple-isotope ratios of the same element (Hulston and Thode, 1965, Matsuhisa et al., 1978). Exceptions for this, however, include the studies of meteorites (e.g., Hulston and Thode, 1965; Gao and Thiemens, 1991; Farquhar et al., 2000b,c) and Archean sedimentary sulfide and sulfate minerals (Farquhar et al., 2000a; Ono et al., 2003), which show anomalous isotope abundance originated in nucleosynthetic processes or gas phase photochemical reactions.

Recent development of multiple-stable isotope analytical capabilities has shown that different isotope mass-dependent fractionation processes (e.g., diffusion, biological metabolism, high temperature equilibrium processes) follow slightly different mass-dependent fractionation laws (Young et al., 2002; Farquhar et al., 2003). These differences are measurable and are documented in multiple isotope systems of oxygen (Angert et al., 2004; Luz et al., 1999), magnesium (Young et al., 2002), and sulfur (Farquhar et al., 2003; Johnston et al., 2005a; Ono et al., 2006). For the sulfur isotope system, Farquhar et al. (2003) and Johnston et al. (2005a) demonstrated that bacterial sulfate reduction follows a mass-dependent relationship that is measurably different (i.e., ${ }^{33} \alpha={ }^{34} \alpha^{0.512}$ ) from that expected from thermochemical equilibrium (i.e., ${ }^{33} \alpha={ }^{34} \alpha^{0.515}$ ). As a result, natural samples can show measurable and systematic variations in $\Delta^{33} \mathrm{~S}\left(\approx \delta^{33} \mathrm{~S}-0.515 \times \delta^{34} \mathrm{~S}\right)$ as well as $\Delta^{36} \mathrm{~S}\left(\approx \delta^{36} \mathrm{~S}-1.90 \times \delta^{34} \mathrm{~S}\right)$ even when $\delta^{34} \mathrm{~S}$ values are identical (Ono et al., 2006). Ono et al. (2006) and Johnston et al. (2005b) discussed how these 
isotope tracers can be used to provide new insights into the post-Archean sulfur biogeochemical cycles. In this paper, we report the first application of multiple-sulfur isotope systematics in the study of the sulfur cycle in modern high temperature seafloor hydrothermal systems.

High temperature seafloor hydrothermal systems circulate the entire world ocean though the oceanic crust every tens of millions of years and strongly impact the global biogeochemical cycles (Stein and Stein, 1994; Kadko et al., 1995; Elderfield and Schultz, 1996). Seawater contains $\sim 28 \mathrm{mmol} / \mathrm{kg}$ of sulfate but, during seafloor hydrothermal circulation, most sulfate precipitates as anhydrite upon heating above $150^{\circ} \mathrm{C}$ in the low temperature recharge zone and only a small fraction $(<1 \mathrm{mmol} / \mathrm{kg}$ ) of sulfate enters to the deep hydrothermal system (Shanks et al., 1981; Sleep, 1991). In the high temperature $\left(>250^{\circ} \mathrm{C}\right)$ reaction zone, the hydrothermal fluid gains $\mathrm{H}_{2} \mathrm{~S}$ through (1) reduction of seawater-derived sulfate by $\mathrm{Fe}^{2+}$ bearing minerals, and (2) leaching of sulfide minerals in basalt (Woodruff and Shanks, 1988; Shanks, 2001). Experimental study shows sulfate reduction is quantitative in the presence of fayalite and magnetite above 250 ${ }^{\circ} \mathrm{C}$ (Mottl et al., 1979; Shanks et al., 1981). If this applies to seafloor hydrothermal systems, the $\delta^{34} \mathrm{~S}$ values $\mathrm{H}_{2} \mathrm{~S}$ reflect two component mixing between seawater derived sulfur $\left(\delta^{34} \mathrm{~S} \approx 21 \%\right.$ ) and rock-derived sulfide $\left(\delta^{34} \mathrm{~S} \approx 0 \%\right.$ ). Based on the two component mixing model, the typical range of $\delta^{34} \mathrm{~S}$ values (1 to $5 \%$; Shanks, 2001) of the present-day hydrothermal sulfide from sediment-free mid-oceanic ridge suggests that most (more than three quarters) of $\mathrm{H}_{2} \mathrm{~S}$ is derived from leaching of basaltic sulfide and seawater-derived sulfate has a relatively small but isotopically significant contribution.

While the two component mixing model explains observed $\delta^{34} \mathrm{~S}$ values of the present day seafloor hydrothermal sulfides, a different model has been developed mostly from studies of ancient seafloor sulfide deposits (e.g., Ohmoto et al. 1983, also see Seal et al., 2000, Shanks, 
2001 for discussion). The anhydrite buffer model (Ohmoto et al., 1983) is isotope fractionationoriented and suggests that $\delta^{34} \mathrm{~S}$ values of hydrothermal $\mathrm{H}_{2} \mathrm{~S}$ (and sulfide minerals) are buffered by previously precipitated anhydrite, and the values of $\delta^{34} \mathrm{~S}$ of sulfides essentially reflect the isotope fractionation factor between sulfate $\left(\mathrm{SO}_{4}\right)$ and sulfide $\left(\mathrm{H}_{2} \mathrm{~S}\right)(\mathrm{Ohmoto}$ et al., 1983; Ohmoto and Goldhaber, 1997). For example, isotope fractionation factors between $\mathrm{SO}_{4}$ and $\mathrm{H}_{2} \mathrm{~S}$ are 21 and $15 \%$ at 300 and $400^{\circ} \mathrm{C}$, respectively (Ohmoto and Lasaga, 1982). Therefore, hydrothermal sulfides with $\delta^{34} \mathrm{~S}$ values between 0 and $6 \%$ are explained by the anhydrite buffered model with equilibrium temperature of 300 and $400^{\circ} \mathrm{C}$, respectively. The anhydrite buffer model implies that the majority of sulfides in seafloor hydrothermal vents are ultimately derived from seawater sulfate, in contrast to the two component mixing model.

Another unresolved issue has been isotope disequilibrium among sulfide minerals and vent fluid $\mathrm{H}_{2} \mathrm{~S}$ collected in-situ (Kerridge et al., 1983; Shanks and Seyfried, 1987; Woodruff and Shanks, 1988; Bluth and Ohmoto, 1988; Shanks et al., 1995; Shanks, 2001). Because experimentally determined isotope fractionation factors among sulfide minerals (pyrite, sphalerite, and chalcopyrite) and $\mathrm{H}_{2} \mathrm{~S}$ are small at typical hydrothermal temperature $(<1.4 \%$ for 300 to $400{ }^{\circ} \mathrm{C}$; Ohmoto and Goldhaber, 1997), observed $\delta^{34} \mathrm{~S}$ variations reflect sulfur isotope disequilibrium among metal sulfides and vent $\mathrm{H}_{2} \mathrm{~S}$. A temporal shift in relative contributions of two sources of sulfur (basaltic sulfide and seawater sulfate) could explain part of isotopic heterogeneity (Bluth and Ohmoto, 1988). Such a temporal change of $\delta^{34} \mathrm{~S}$ for vent fluid $\mathrm{H}_{2} \mathrm{~S}$ from +6.4 to $+2.9 \%$ was reported by a time-series sampling at $9-10^{\circ} \mathrm{N}$ East Pacific Rise (EPR) (Shanks, 2001). However, Shanks (2001) also reported that isotope disequilibrium still exists with vent fluid $\mathrm{H}_{2} \mathrm{~S}$ being one to two permil enriched in ${ }^{34} \mathrm{~S}$ relative to metal sulfides even after careful sampling of metal sulfides in the inner-wall of chimneys. An alternative model involves 
local reduction of seawater sulfate by entrainment of seawater through chimney walls and/or by dissolution of previously precipitated anhydrite (Woodruff and Shanks, 1988; Janecky and Shanks, 1988). Concentrations of reducing agents $\left(\mathrm{H}_{2}\right.$ and $\left.\mathrm{Fe}^{2+}\right)$ in hydrothermal fluid, however, appear too low to explain all local isotope variations (Bluth and Ohmoto, 1988). More recent studies, however, have shown large ranges of $\mathrm{H}_{2}$ and $\mathrm{Fe}^{2+}$ concentration in hydrothermal fluids due to, in part, phase separation (Von Damm, 2000; Seyfried and Shanks, 2004).

As we see in the two contrasting interpretations, isotope mixing and fractionation can result in identical values for $\delta^{34} \mathrm{~S}$. In this contribution, we show that precise analysis of $\Delta^{33} \mathrm{~S}$ values provides an additional constraint that can be used to decouple isotope mixing from fractionation. The isotope systematics discussed here are applicable to a variety of problems not only for sulfur isotope but also for any isotope systems that have more than two isotopes (e.g., ${ }^{16,17,18} \mathrm{O}$, ${ }^{24,25,26} \mathrm{Mg},{ }^{54,56,57,58} \mathrm{Fe},{ }^{74,76,77,78,80,82} \mathrm{Se}$ ) as long as the required analytical precision can be achieved.

\section{DEFINITIONS AND NOTATIONS}

Sulfur isotope values are reported using the conventional delta notation:

$$
\delta^{\mathrm{x}} \mathrm{S}=\left(\frac{{ }^{\mathrm{x}} R_{\text {sample }}}{{ }^{\mathrm{x}} R_{\text {reference }}}-1\right) \times 1,000
$$

where ${ }^{\mathrm{x}} R$ is the isotope ratio, ${ }^{\mathrm{x}} \mathrm{S} /{ }^{32} \mathrm{~S}(\mathrm{x}=33,34$ or 36$)$, of the sample and reference materials. By convention, sulfur isotope data are referenced to the Vienna-Cañon Diablo Troilite scale (VCDT) by defining $\delta^{34}$ S of IAEA S-1 (artificial $\mathrm{Ag}_{2} \mathrm{~S}$ ) to be $-0.3 \%$ (Coplen and Krouse, 1998). In this paper, the multiple-sulfur isotope VCDT scale is defined by IAEA S-1 having $-0.055,-0.300$, 
and $-1.37 \%$ for $\delta^{33} \mathrm{~S}, \delta^{34} \mathrm{~S}$ and $\delta^{36} \mathrm{~S}$, respectively. These values are derived from average values of CDT and IAEA S-1 measured in this and in our previous studies (Ono et al., 2006).

We define capital delta notation $(\Delta)$ as the deviation of $\delta^{33} \mathrm{~S}$ from a reference line (Hulston and Thode, 1965; Gao and Thiemens, 1991) :

$$
\Delta^{33} S=\delta^{33} S-0.515 \times \delta^{34} S
$$

An alternative definition has been used by recent studies (Miller, 2002; Young et al., 2002; Ono et al., 2003, Ono et al., 2006), and we denote this as $\Delta^{*}$ :

$$
\Delta^{33} S^{*}=\delta^{33} S^{*}-0.515 \times \delta^{34} S^{*}
$$

where

$$
\delta^{x} \mathrm{~S}^{*}=\ln \left(\frac{{ }^{x} R_{\text {sample }}}{{ }^{x} R_{\text {ref }}}\right) \times 1,000=\ln \left(\frac{\delta^{x} \mathrm{~S}}{1,000}+1\right) \times 1,000
$$

These definitions of $\Delta^{*}$ and $\delta^{*}$ are often preferred because of logarithmic relationships between mass-dependent isotope fractionations (Hulston and Thode, 1965; Miller, 2002; Young et al., 2002), such that :

$$
{ }^{33} \theta \approx \frac{\ln \left({ }^{33} \alpha\right)}{\ln \left({ }^{34} \alpha\right)}
$$

where ${ }^{\mathrm{x}} \alpha$ is the isotope fractionation factor (e.g., ${ }^{\mathrm{x}} \alpha={ }^{\mathrm{x}} R_{\mathrm{A}} /{ }^{\mathrm{x}} R_{\mathrm{B}}$ ). Several papers discuss characteristics of different definitions used in multiple-isotope studies (e.g., Miller, 2002; Young et al., 2002; Kaiser et al., 2004; Assonov and Brenninkmeijer, 2005; Ono et al., 2006). We use both definitions ( $\Delta$ and $\left.\Delta^{*}\right)$ in this paper because there is no best coordinate system in describing mathematics of multiple-stable isotope systematics. It will be shown that the alternative delta 
notations $\left(\delta^{34} \mathrm{~S}^{*}\right.$ and $\left.\Delta^{33} \mathrm{~S}^{*}\right)$ are fractionation oriented whereas traditional delta coordinates $\left(\delta^{34} \mathrm{~S}\right.$ and $\Delta^{33} \mathrm{~S}$ ) are mass-balance oriented.

In principle, the fourth isotope, ${ }^{36} \mathrm{~S}$, carries additional information to ${ }^{32} \mathrm{~S} /{ }^{33} \mathrm{~S} /{ }^{34} \mathrm{~S}$. We define:

$$
\Delta^{36} S=\delta^{36} S-1.90 \times \delta^{34} S
$$

and

$$
\Delta^{36} S^{*}=\delta^{33} S^{*}-1.90 \times \delta^{34} S^{*}
$$

In our previous study, however, it was shown that $\Delta^{33} \mathrm{~S}^{*}$ and $\Delta^{36} \mathrm{~S}^{*}$, behave mathematically similarly, with general negative correlations with $\Delta^{36} \mathrm{~S}^{*} / \Delta^{33} \mathrm{~S}^{*} \approx-7$ (Ono et al., 2006). This general correlation depends on a number of factors (e.g., temperature, fractionation processes) but accuracy of $\Delta^{36} \mathrm{~S}$ measurements is not sufficient to derive additional information for the range of $\Delta^{33} \mathrm{~S}$ values for this study. Therefore, we report $\delta^{36} \mathrm{~S}$ values but do not discuss their isotope systematics.

\section{MATERIALS}

\section{East Pacific Rise (EPR) $9-10^{\circ} \mathrm{N}$}

The seafloor hydrothermal vent sites at $9-10^{\circ} \mathrm{N}$ East Pacific Rise (EPR) are located on a fast spreading (10.2 cm/year full spreading rate) ridge at 2512 to $2580 \mathrm{~m}$ depth (Von Damm, 2000). The vent fluid $\mathrm{H}_{2} \mathrm{~S}$ and chimney-wall metal-sulfide samples were collected in 1994 from four different vent sites spread over $24 \mathrm{~km}$ along the ridge axis (Shanks, 2001). Temperature, 
$\mathrm{H}_{2} \mathrm{~S}$ content, and the $\delta^{34} \mathrm{~S}$ values of the fluids range from 342 to $377^{\circ} \mathrm{C}, 5.0$ to $8.5 \mathrm{mmol} / \mathrm{kg}$, and 4.8 to $5.3 \%$, respectively (Shanks, 2001).

\section{$\operatorname{EPR} 13^{\circ} \mathbf{N}$}

Sulfide samples were collected from an active hydrothermal chimney at $13^{\circ} \mathrm{N}$ EPR $\left(12^{\circ}\right.$ $48^{\prime} \mathrm{N}$ ) at water depth of $2630 \mathrm{~m}$. Mineral separates of pyrite and sphalerite were analyzed for sulfur isotope compositions. The $13^{\circ} \mathrm{N}$ EPR is a fast spreading center $(10.4 \mathrm{~cm} /$ year full spreading rate), and hydrothermal vents emit fluid of up to $380^{\circ} \mathrm{C}$ with $\mathrm{H}_{2} \mathrm{~S}$ of 2.9 to 12.2 $\mathrm{mmol} / \mathrm{kg}$ (Bluth and Ohmoto, 1988). Bluth and Ohmoto (1988) reported $\delta^{34} \mathrm{~S}$ of sulfide averages $4.1 \pm 0.6 \%$.

\section{EPR $21^{\circ} \mathrm{S}$}

An active chimney sample was collected from the Brandon vent at $21^{\circ} \mathrm{S}$ EPR (Von Damm, et al., 2003). The EPR at $21^{\circ} \mathrm{S}$ is an ultra-fast spreading center with full spreading rate at $15.2 \mathrm{~cm} /$ year. The samples came from one of the five chimneys at the Brandon Site. The vents from the Brandon site are characterized by high temperature fluids (up to $400^{\circ} \mathrm{C}$ ), which is close to the critical point of the fluids at ambient pressure of 287 bars $(2834 \mathrm{~m})$ (Von Damm et al., 2003).

\section{Mid-Atlantic Ridge (MAR) $37^{\circ} \mathrm{N}$, Lucky Strike vent field}

Lucky Strike vent field is located at $37^{\circ} 17^{\prime} \mathrm{N}$ on the Mid-Atlantic Ridge, and characterized by a slow spreading $(2.4 \mathrm{~cm} /$ year full rate) ridge, and vent fluids temperatures of up to $324^{\circ} \mathrm{C}$ at depth of 1618- $1726 \mathrm{~m}$ (Charlou et al., 2000; Von Damm et al., 1998). A 
previous study of sulfur isotope values of sulfide minerals reported $\delta^{34} \mathrm{~S}$ of -0.5 to $+4.6 \%$ (Rouxel et al., 2004). Mineral separates of marcasite and chalcopyrite from the Bairo Alto chimney were analyzed in this study.

\section{ANALYTICAL METHOD}

A laser fluorination $\mathrm{SF}_{6}$ manifold was developed to measure all three isotope ratios of sulfur $\left({ }^{33} \mathrm{~S} /{ }^{32} \mathrm{~S},{ }^{34} \mathrm{~S} /{ }^{32} \mathrm{~S}\right.$ and $\left.{ }^{36} \mathrm{~S} /{ }^{32} \mathrm{~S}\right)$. Detailed description of the technique can be found in Hu et al. (2003) and Ono et al. (2006). Briefly, the sample, either silver sulfide powder $(\sim 1.5 \mathrm{mg})$ or sulfide mineral separate (weighed to yield $\sim 6 \mu \mathrm{mol} \mathrm{S}$ ) is heated by a $\mathrm{CO}_{2}$ laser in elemental fluorine of 25 to 30 torr. A newly developed multi-dimensional (two stage) gas chromatography (GC) system allows high-precision analyses of all three sulfur isotope ratios at precision better than 0.01 and $0.2 \%$ for $\Delta^{33} \mathrm{~S}$ and $\Delta^{36} \mathrm{~S}$, respectively (Ono et al., 2006). The GC system consists of two sets of packed columns. The first column is packed with molecular sieve $5 \AA$ (60-80 mesh, 1/8 inch OD, $2.0 \mathrm{~m}$ ) linked with a column packed with Hayesep Q (80-100 mesh, 1/8 inch OD, $2.4 \mathrm{~m})$ and the second column is packed with Hayesep Q (80-100 mesh, 1/8 inch OD, $2.0 \mathrm{~m})$. Both columns are operated with a He flow rate at $25 \mathrm{~mL} / \mathrm{min}$ at temperature of $100^{\circ} \mathrm{C}$. The analyte is heart cut twice from the first column to the second, and from the second column to a cold trap held at liquid nitrogen temperature. After evacuating He carrier gas, the purified $\mathrm{SF}_{6}$ is introduced to an isotope ratio mass-spectrometry by using a dual-inlet mode.

The mass-spectrometer (Thermo-electron MAT 253) has faraday cups that allow simultaneous determination of masses $127,128,129$, and $131\left({ }^{32} \mathrm{SF}_{5}^{+},{ }^{33} \mathrm{SF}_{5}^{+},{ }^{34} \mathrm{SF}_{5}^{+}\right.$, and ${ }^{36} \mathrm{SF}_{5}^{+}$, respectively). The dual-inlet analysis consists of three to five runs. Each run consists of eight 
cycles of reference versus sample injection. The $\delta^{33} \mathrm{~S}, \delta^{34} \mathrm{~S}$, and $\delta^{36} \mathrm{~S}$ values are derived from average of these runs. The values of $\Delta^{33} \mathrm{~S}$ and $\Delta^{36} \mathrm{~S}$ are calculated for each run, and the average of runs is reported (Table 1).

Eight fluorination analyses of IAEA S-1 over an eight month period are shown in Table 1 along with those of two CDT samples and one NBS reference sample (NBS OGS-1). These measurements reflect precision for complete analysis from fluorination, GC purification, and dual-inlet mass-spectrometry analysis. Reproducibilities for $\delta^{33} \mathrm{~S}, \delta^{34} \mathrm{~S}$ and $\delta^{36} \mathrm{~S}$ for IAEA S-1 are $0.14,0.26$ and $0.50 \%(1 \sigma)$, respectively (Table 1$)$. While these values are typical precisions for isotope ratio measurements, precisions for $\Delta^{33} \mathrm{~S}$ and $\Delta^{36} \mathrm{~S}$ are 0.006 and $0.20 \%(2 \sigma)$, respectively (Table 1). This is because most errors for isotope ratio analyses $\left(\delta^{33} \mathrm{~S}, \delta^{34} \mathrm{~S}\right.$ and $\delta^{36} \mathrm{~S}$ ) are due to chemistry of fluorination reactions (e.g., possible formation of $\mathrm{SOF}_{2}$ ) and transfer of $\mathrm{SF}_{6}$ in the vacuum line and GC system. Both of these processes are mass-dependent, and thus, contribute correlated errors for $\delta^{33} \mathrm{~S}$ and $\delta^{34} \mathrm{~S}$ that cancel each other during the calculation of $\Delta^{33} \mathrm{~S}$ values. The precisions of $\Delta^{33} \mathrm{~S}$ and $\Delta^{36} \mathrm{~S}$, in contrast, are often limited by dual-inlet mass-spectrometry, such as ion counting statistics and instrumental stability. Table 2 summarizes isotope compositions of reference materials measured in this and previous studies (Ono et al., 2006).

\section{RESULTS}

\section{EPR 9-10 $N$}

The $\delta^{34} \mathrm{~S}$ values of chimney-wall metal-sulfides range from 1.3 to $3.4 \%$ whereas vent $\mathrm{H}_{2} \mathrm{~S}$ collected in-situ ranges from 4.4 to $5.8 \%$ (Table 3; Figure 1-A). Comparing metal sulfide and $\mathrm{H}_{2} \mathrm{~S}$ pairs collected from the same sites, the vent fluid $\mathrm{H}_{2} \mathrm{~S}$ is enriched in ${ }^{34} \mathrm{~S}$ by 1.2 to $3.5 \%$, 
consistent with previous reports (Shanks, 2001). The $\Delta^{33} \mathrm{~S}$ values of vent $\mathrm{H}_{2} \mathrm{~S}$ range from 0.008 to $0.045 \%$ and are relatively higher than those of the metal sulfides $(0.000$ to $0.022 \%$ ) (Figure $1-\mathrm{A})$.

\section{EPR $13^{\circ} \mathbf{N}$}

Chalcopyrite $\delta^{34} \mathrm{~S}$ values are from 2.0 to $2.6 \%$, which are higher than those of pyrite $(0.4$ to $1.0 \%$; Table 3 ). This is the reverse from the expected relationship for isotope equilibrium, where pyrite is enriched in ${ }^{34} \mathrm{~S}$ by $0.8 \pm 0.1 \%$ at temperature between 300 and $400{ }^{\circ} \mathrm{C}$ (Ohmoto and Goldhaber, 1997). The $\Delta^{33} \mathrm{~S}$ values range from -0.002 to $0.031 \%$, with a linear correlation between $\delta^{34} \mathrm{~S}$ and $\Delta^{33} \mathrm{~S}$ (Figure 1-B).

\section{$\operatorname{EPR} 21^{\circ} \mathrm{S}$}

Sphalerite $\delta^{34} \mathrm{~S}$ values are from 4.9 to $5.3 \%$ and are higher than those of chalcopyrite (4.5\%o). Sphalerite also yields slightly higher $\Delta^{33} \mathrm{~S}$ values of 0.008 to $0.009 \%$, compared to chalcopyrite (0.002 to $0.005 \%$ ) (Table 3; Figure 1-C).

\section{$\operatorname{MAR} 37^{\circ} \mathrm{N}$, Lucky Strike vent field}

The $\delta^{34} \mathrm{~S}$ of marcasite ranges from -0.9 to $0.5 \%$ and $\delta^{34} \mathrm{~S}$ of chalcopyrite ranges from 1.7 to $3.6 \%$, consistent with a previous report (Rouxel et al., 2004). This relationship is opposite from what is expected for isotope equilibrium, where pyrite is enriched relative to pyrite by $1.2 \pm 0.2 \%$ at temperatures between 300 and $400{ }^{\circ} \mathrm{C}$. The $\Delta^{33} \mathrm{~S}$ values range from 0.007 to $0.033 \%$, and correlate with $\delta^{34} \mathrm{~S}$ (Figure 1-D). 


\section{DISCUSSION}

\subsection{Triple-sulfur isotope systematics of seafloor hydrothermal sulfides}

\subsubsection{Two component mixing model}

A two component mixing model is formulated whereby the $\delta^{34} \mathrm{~S}$ value of hydrothermal sulfide (HTS) is set by the isotope compositions of basalt-derived and seawater-derived sulfur and mixing ratios between the two:

$$
\delta^{\mathrm{x}} \mathrm{S}_{\mathrm{HTS}}={ }^{32} f_{\text {basalt }} \delta^{\mathrm{x}} S_{\text {basalt }}+\left(1-{ }^{32} f_{\text {basalt }}\right) \delta^{\mathrm{x}} S_{\text {seawater }}
$$

where ${ }^{32} f_{\text {basalt }}$ is the ${ }^{32} \mathrm{~S}$ normalized mole fraction of sulfide derived from basalt (i.e., ${ }^{32} f_{\text {basalt }}={ }^{32} \mathrm{~S}_{\text {basalt }}{ }^{32} \mathrm{~S}_{\mathrm{HTS}}$ ). Equation (8) is exact when the fractional abundance of ${ }^{32} \mathrm{~S}$ is used instead of the fraction of total sulfur (i.e., ${ }^{32} \mathrm{~S}+{ }^{33} \mathrm{~S}+{ }^{34} \mathrm{~S}+{ }^{36} \mathrm{~S}$ ). In practice, however, an approximation, ${ }^{32} f \approx f$, is valid for sulfur isotope systems (Ono et al., 2006). One can also derive a similar isotope mass balance equation for $\Delta^{33} \mathrm{~S}$ :

$$
\Delta^{33} \mathrm{~S}_{\mathrm{HTS}}={ }^{32} f_{\text {basalt }} \Delta^{33} \mathrm{~S}_{\text {basalt }}+\left(1-{ }^{32} f_{\text {basalt }}\right) \Delta^{33} \mathrm{~S}_{\text {seawater }}
$$

Multiple-sulfur isotope compositions of the two end-member components are defined in order to solve equations (8) and (9).

Oceanic basalts contain 500 to $1500 \mathrm{ppm}$ sulfur as iron-monosulfide solid-solution (approximately pyrrhotite) with $\delta^{34} \mathrm{~S}$ values typically within $\pm 1 \%$ of CDT (Sakai et al., 1982, 1984; Kusakabe et al., 1990). Most meteorites, except for some minor phases, as well as lunar basalts yield $\Delta^{33} \mathrm{~S}$ values statistically indistinguishable from that of CDT (Gao and Thiemens, 1991, 1993a,b; Farquhar and Wing, 2005), suggesting that $\delta^{34} S$ and $\Delta^{33} S$ values of the Earth's primordial sulfur are similar to those of CDT (Farquhar et al., 2002; Ono et al., 2006). Sakai et al. (1982) reported that sulfate-sulfur fractions in basalts are enriched in ${ }^{34} \mathrm{~S}$ up to $10 \%$ but these 
sulfate fractions may contribute little because of their low reactivity (Woodruf and Shanks, 1988). Therefore, following Woodruff and Shanks (1988), Farquhar et al., (2002), Johnston et al. (2005b), and Ono et al., (2006), we assume that the $\delta^{34} S$ and $\Delta^{33} S$ values of sulfide in the midoceanic basalts are close to those of CDT (i.e., $\delta^{34} \mathrm{~S}_{\text {basalt }} \approx \Delta^{33} \mathrm{~S}_{\text {basalt }} \approx 0$ ).

Rees (1978) has shown that seawater sulfate has nearly constant $\delta^{34}$ S value of $21 \%$, reflecting the long residence time of sulfate in the oceans ( $\sim 28 \mathrm{Ma}$; Garrels and Lerman, 1981; Holser et al., 1989). Two international reference materials (IAEA S-2 and OGS-1) originating from seawater sulfate (Robinson, 1993) yield $\Delta^{33} \mathrm{~S}$ values of $-0.009 \pm 0.006$ and $-0.007 \pm 0.004$ $(2 \sigma)$, respectively (Table 2). We used the average of these two reference materials as the model isotope compositions of seawater sulfate (i.e., $\delta^{33} \mathrm{~S}=11.1, \delta^{34} \mathrm{~S}=21.5$ and $\Delta^{33} \mathrm{~S}=-0.008 \%$ ).

Solid lines in Figure 2 show graphical representations of the two component mixing model (equations (8) and (9)). The two component mixing model is expressed linearly in traditional $\delta$ vs. $\Delta$ coordinates (Figure 2-A). Isotope mixing, however, is curved in the modified $\delta^{34} S^{*}$ vs. $\Delta^{33} S^{*}$ coordinates (Figure 2-B; Ono et al., 2006) .

\subsubsection{Anhydrite buffer model}

The isotope composition of $\mathrm{H}_{2} \mathrm{~S}$ expected for the anhydrite buffer model is derived using the isotope compositions of seawater sulfate and the equilibrium isotope fractionation factor between sulfate $\left(\mathrm{SO}_{4}\right)$ and sulfide $\left(\mathrm{H}_{2} \mathrm{~S}\right)$ that is a function of temperature. Sulfur isotope fractionation factors among sulfate minerals (barite and anhydrite) and $\mathrm{SO}_{4}$ are not considered because this is minor compared to that between $\mathrm{SO}_{4}$ and $\mathrm{H}_{2} \mathrm{~S}$ (Ohmoto et al., 1983). Isotope fractionation factors have not been determined experimentally for ${ }^{33} \mathrm{~S}$ and ${ }^{36} \mathrm{~S}$ between $\mathrm{SO}_{4}$ and $\mathrm{H}_{2} \mathrm{~S}$. We estimated relationships among three isotope fractionation factors $\left({ }^{33} \theta\right.$ and $^{36} \theta$ in 
equation (5)) by using a semiclassical isotope fractionation theory of Urey (1947) (Table 4). The fundamental frequencies of $\mathrm{SO}_{4}$ and $\mathrm{H}_{2} \mathrm{~S}$ are taken from Urey (1947) and Nakamoto (1997), and the vibrational frequency shifts are calculated by using the modified Urey-Bradley force field model following a scheme outlined in Schauble (2004) and Nakamoto (1997). The calculated isotope fractionation factor for ${ }^{34} \mathrm{~S} /{ }^{32} \mathrm{~S}\left({ }^{34} \alpha\right.$ ) is consistent (within $\pm 1 \%$ ) with the empirical fit for experimental studies (Ohmoto and Lasaga, 1982) as well as previous theoretical calculation (Sakai, 1968) between 200 and $400^{\circ} \mathrm{C}$.

The relationships among intra-elemental fractionation factors for $\mathrm{SO}_{4}$ and $\mathrm{H}_{2} \mathrm{~S}$ are best described by a logarithmic formula, and fitted by the following empirical equations:

$$
{ }^{33} \theta=\frac{\ln \left({ }^{33} \alpha\right)}{\ln \left({ }^{34} \alpha\right)}=-\frac{9.460}{T^{2}}-\frac{0.3117}{T}+0.5159
$$

and

$$
{ }^{36} \theta=\frac{\ln \left({ }^{36} \alpha\right)}{\ln \left({ }^{34} \alpha\right)}=\frac{59.18}{T^{2}}+\frac{2.449}{T}+1.891
$$

where ${ }^{x} \alpha$ are isotope fractionation factors, and temperature $(T)$ is in Kelvin. At high temperature $(\mathrm{T} \rightarrow \infty)$ the ${ }^{33} \theta$ value approaches 0.5159 , which is expected from the high temperature approximation (Matsuhisa et al., 1978; Young et al., 2002):

$$
{ }^{33} \theta_{\text {high }-T}=\left(\frac{1}{{ }^{33} m}-\frac{1}{{ }^{32} m}\right) /\left(\frac{1}{{ }^{34} m}-\frac{1}{{ }^{32} m}\right)=0.5159
$$

where ${ }^{\mathrm{x}} m$ is an atomic mass for ${ }^{\mathrm{x}} \mathrm{S}$.

The isotope compositions of $\mathrm{H}_{2} \mathrm{~S}$ that is in isotope equilibrium with the model seawater $\mathrm{SO}_{4}$ is derived as a function of temperature and shown in Figure 2. It is shown that the expected $\Delta^{33} \mathrm{~S}\left(\right.$ or $\Delta^{33} \mathrm{~S}^{*}$ ) value for the anhydrite buffer model is higher than the two component mixing 
model even when $\delta^{34} \mathrm{~S}$ values are identical. The curvature in the anhydrite buffer model in $\delta^{34} \mathrm{~S}$ vs. $\Delta^{33} \mathrm{~S}$ coordinates (Figure 2-A) is due to the logarithmic relationship of mass-dependent fractionation (i.e., equation (10)). The curvature becomes practically linear in $\delta^{34} S^{*} v s . \Delta^{33} S^{*}$ coordinates (Figure 2-B)

\subsection{Decoupling mixing and isotope exchange}

Measured $\Delta^{33} \mathrm{~S}$ and $\delta^{34} \mathrm{~S}$ values for seafloor vent sulfides do not fall exactly on the expected isotope compositions for either the two component mixing or anhydrite buffer model, indicating that the data show that both mixing and fractionation are important in determining the isotope composition of hydrothermal sulfides (Figure 1).

Experimental study shows that sulfate is quantitatively reduced when fayalite (or more precisely, the fayalite component of olivine) is present at temperature above $250^{\circ} \mathrm{C}$ (Shanks et al., 1981):

$$
6 \mathrm{Fe}_{2} \mathrm{SiO}_{4}+\mathrm{SO}_{4}{ }^{2-}+2 \mathrm{H}^{+} \rightarrow 4 \mathrm{Fe}_{3} \mathrm{O}_{4}+\mathrm{H}_{2} \mathrm{~S}+6 \mathrm{SiO}_{2}
$$

In the natural system, this reaction occurs in the low water/rock ratio system where redox of the fluid is buffered by the quartz-fayalite-magnetite mineral assemblage (Seyfried and Ding, 1995). Sulfate entering into this rock buffered deep reaction zone, typically 1 to $2 \mathrm{~km}$ depth, is quantitatively reduced into $\mathrm{H}_{2} \mathrm{~S}$. The $\mathrm{H}_{2} \mathrm{~S}$ produced in such a process would have sulfur isotope compositions that follow the two component mixing line.

Upflow of the hydrothermal fluid from the deep reaction zone may involve significant entrainment of seawater. Such sulfate entrainment is well documented, for example, at the Trans-Atlantic Geotraverse (TAG) field (Humphris and Tivey, 2000), where anhydrite is precipitated in the shallow subseafloor (to the depths of about $100 \mathrm{~m}$ ). When hydrothermal 
fluids upflow through anhydrite-bearing zones, the sulfur isotope composition of the fluid $\mathrm{SO}_{4}$ would be maintained by reversible dissolution/precipitation of anhydrite:

$$
\mathrm{Ca}^{2+}+\mathrm{SO}_{4}^{2-} \leftrightarrow \mathrm{CaSO}_{4}
$$

and isotope exchange between $\mathrm{SO}_{4}$ and $\mathrm{H}_{2} \mathrm{~S}$ controls $\delta^{34} \mathrm{~S}$ and $\Delta^{33} \mathrm{~S}$ values of $\mathrm{H}_{2} \mathrm{~S}$. When isotope equilibrium is established, the isotope composition of $\mathrm{H}_{2} \mathrm{~S}$ would fall on the anhydrite buffer line at the corresponding temperature. When isotope equilibrium is not established, the isotope composition of $\mathrm{H}_{2} \mathrm{~S}$ would fall between the two component mixing endmember and the anhydrite buffer endmember (Figure 3). An example application of this mixing-reaction model is applied to the $9-10^{\circ} \mathrm{N}$ system (Figure 3), where the two-component mixing ratio is 0.17 in the deep reaction zone (deep $\mathrm{H}_{2} \mathrm{~S}$ ) and subsequent isotope exchange with $\mathrm{SO}_{4}$ occurs at $\sim 300^{\circ} \mathrm{C}$ or $400^{\circ}$ $\mathrm{C}$ (Line A and B in Figure 3, respectively).

The sulfur isotope data for vent $\mathrm{H}_{2} \mathrm{~S}$ from EPR 9-10 ${ }^{\circ} \mathrm{N}$ suggests isotope exchange between $\mathrm{H}_{2} \mathrm{~S}$ and $\mathrm{SO}_{4}$ at $400^{\circ} \mathrm{C}$ for samples 2756-14 and 2736-12 (Figure 3). A lower temperature $\left(329^{\circ} \mathrm{C}\right)$ was measured $i n-s i t u$ for venting fluid at 2736 (Shanks, 2001), suggesting that isotope exchange between $\mathrm{SO}_{4}$ and $\mathrm{H}_{2} \mathrm{~S}$ occurred in the subsurface prior to venting at the seafloor. Higher temperatures (above $400^{\circ} \mathrm{C}$ ) are estimated for samples 2752-11 and 2748-14, which also are higher than in-situ temperatures of 377 and $342{ }^{\circ} \mathrm{C}$, respectively. Isotope exchange at temperatures significantly above $400^{\circ} \mathrm{C}$, however, is unlikely due to constraints of phase separation (Bischoff and Rosenbauer, 1988) because chemistry of the sampled fluids (e.g., chloride concentrations) does not show evidence of phase separation (Shanks, 2001).

At the temperature of $400^{\circ} \mathrm{C}$ isotope equilibrium between $\mathrm{H}_{2} \mathrm{~S}$ and $\mathrm{SO}_{4}$ is established in 14 to 70 hours at $\mathrm{pH}$ between 3 and $4(90 \%$ exchange for total $\mathrm{S}$ content of $10 \mathrm{mmol} / \mathrm{kg}$, Ohmoto and Lasaga, 1982). Except for one sample (2756-14), $\delta^{34} \mathrm{~S}$ and $\Delta^{33} \mathrm{~S}$ of the vent $\mathrm{H}_{2} \mathrm{~S}$ fall between 
two component mixing and anhydrite buffer line, indicating incomplete isotope exchange between $\mathrm{SO}_{4}$ (and anhydrite) and $\mathrm{H}_{2} \mathrm{~S}$. This suggests that the timescales of isotope exchange and residence time of fluid in the anhydrite-buffered zone are both on the order of hours to a few days. If the vertical velocity of the subsurface fluid upflow can be approximated to that of the fluid venting at black smoker chimneys, which is on the order of $1 \mathrm{~m} / \mathrm{s}$, it would take less than one hour for hydrothermal fluid to travel from the deep reaction zone $(\sim 2 \mathrm{~km})$ to the seafloor (Alt, 1995a; Shanks, 2001). Because this is too fast compared to sulfur isotope exchange kinetics, our isotope data suggest slower subsurface upflow velocity and focusing of the flow through the chimney orifice. This is consistent with the model by Fisher (2004) that estimates residence time of fluids in subseafloor hydrothermal systems to be on the order of 1-10 years. Detailed studies of $\delta^{34} \mathrm{~S}-\Delta^{33} \mathrm{~S}$ may help resolve the residence time of fluids in the shallow anhydrite bearing rock system.

\subsection{Isotope disequilibrium among sulfide minerals and pyrite precipitation mechanism}

Pyrite in seafloor hydrothermal systems often yields lower $\delta^{34} \mathrm{~S}$ values compared to vent $\mathrm{H}_{2} \mathrm{~S}$, sphalerite, and chalcopyrite (Kerridge et al., 1983; Shanks and Seyfried, 1987; Woodruff and Shanks, 1988; Bluth and Ohmoto, 1988; Rouxel et al., 2004). This relationship is opposite to what is expected for isotope equilibrium (Ohmoto and Goldhaber, 1997). In this study, pyrite from the EPR $13^{\circ} \mathrm{N}$ and marcasite from the Lucky Strike vent field, are found to be in isotope disequilibrium with sphalerite and chalcopyrite not only in $\delta^{34} \mathrm{~S}$ but also in $\Delta^{33} \mathrm{~S}$.

Although pyrite is an abundant mineral in both modern and ancient seafloor hydrothermal sulfide deposits, its precipitation pathway(s) has been controversial (Rickard, 1997; Wilkin and 
Barnes, 1996; Benning et al., 2000; Schoonen, 2004, and references therein). Experimental studies show that pyrite can precipitate from FeS precursors by reactions with thiosulfate or polythionate (Schoonen and Barnes, 1991):

$$
\begin{aligned}
& \mathrm{FeS}+\mathrm{S}_{2} \mathrm{O}_{3}^{2-} \rightarrow \mathrm{FeS}_{2}(\mathrm{~s})+\mathrm{SO}_{3}^{2-} \\
& \mathrm{FeS}+\mathrm{S}_{\mathrm{n}} \mathrm{O}_{6}^{2-} \rightarrow \mathrm{FeS}_{2}(\mathrm{~s})+\mathrm{S}_{\mathrm{n}-1} \mathrm{O}_{6}^{2-}
\end{aligned}
$$

An alternative mechanism for pyrite precipitation can be written as:

$$
\mathrm{FeS}+\mathrm{H}_{2} \mathrm{~S} \rightarrow \mathrm{FeS}_{2}+\mathrm{H}_{2}
$$

Following this " $\mathrm{H}_{2} \mathrm{~S}$ pathway" (Rickard, 1997), oxidation of $\mathrm{S}$ in $\mathrm{H}_{2} \mathrm{~S}$ to $\mathrm{FeS}_{2}\left(\mathrm{~S}^{2-}\right.$ to $\mathrm{S}^{-}$) is coupled by reduction of $\mathrm{H}\left(\mathrm{H}^{+}\right.$to $\left.\mathrm{H}^{0}\right) . \mathrm{H}_{2} \mathrm{~S}$ is the dominant sulfide species in seafloor hydrothermal fluids, but oxidative reaction with ambient sulfate is likely to produce thiosulfate or other intermediates.

We suggest the following three steps for precipitation of pyrite in seafloor hydrothermal systems via thiosulfate intermediates:

$$
\begin{aligned}
& \mathrm{H}_{2} \mathrm{~S}+* \mathrm{SO}_{4}{ }^{2-}+2 \mathrm{H}^{+} \leftrightarrow \mathrm{H}_{2} \mathrm{~S}-* \mathrm{SO}_{3}+\mathrm{H}_{2} \mathrm{O} \\
& \mathrm{H}_{2} \mathrm{~S}-* \mathrm{SO}_{3} \leftrightarrow \mathrm{H}_{2} * \mathrm{~S}-\mathrm{SO}_{3} \\
& \mathrm{FeS}+\mathrm{H}_{2} * \mathrm{~S}-\mathrm{SO}_{3} \rightarrow \mathrm{FeS} * \mathrm{~S}+\mathrm{SO}_{3}{ }^{2-}+2 \mathrm{H}^{+}
\end{aligned}
$$

where sulfur derived from seawater is labeled as $* \mathrm{~S}$. A thiosulfate intermediate $\left(\mathrm{H}_{2} \mathrm{~S}-\mathrm{SO}_{3}\right)$ is formed by association of $\mathrm{H}_{2} \mathrm{~S}$ and $\mathrm{SO}_{4}{ }^{2-}$ (reaction (18)), followed by intra-molecular sulfur exchange of sulfane $\left(\mathrm{H}_{2} \mathrm{~S}\right)$ - and sulfonate $\left(\mathrm{SO}_{3}\right)$-sulfur (reaction (19)), and precipitation of pyrite using the sulfane-sulfur of thiosulfate (reaction (20)). In the overall reaction,

$$
\mathrm{FeS}+\mathrm{SO}_{4}{ }^{2-}+\mathrm{H}_{2} \mathrm{~S} \rightarrow \mathrm{FeS}_{2}+\mathrm{SO}_{3}{ }^{2-}+\mathrm{H}_{2} \mathrm{O}
$$


sulfate is used to oxidize sulfur in $\mathrm{H}_{2} \mathrm{~S}$ to form pyrite, a similar mechanism proposed by Woodruff and Shanks (1988). Relatively enriched $\Delta^{33} \mathrm{~S}$ values for pyrite suggest that sulfate reduction (reaction (21)) involves isotope exchange with $\mathrm{SO}_{4}$ (i.e., equation 18-20) rather than quantitative reduction of sulfate coupled with $\mathrm{H}_{2}$ or $\mathrm{Fe}^{2+}$, which would result in $\Delta^{33} \mathrm{~S}$ values following a two component mixing line. The reaction (21) is quantitatively reasonable because sulfate is the most abundant electron acceptor $(\sim 28 \mathrm{mmol} / \mathrm{kg})$ compared with other oxidants such as oxygen (140-260 $\mu \mathrm{mol} / \mathrm{kg}$ ) or nitrate (18 to $36 \mu \mathrm{mol} / \mathrm{kg})$ in deep ocean water (Broecker and Peng, 1982). Sulfate can be supplied to hydrothermal solution from dissolution of previously precipitated anhydrite within chimney structures or by entrainment of ambient seawater.

Following the two stage model, linear correlations between $\delta^{34} \mathrm{~S}$ and $\Delta^{33} \mathrm{~S}$ seen in sulfide minerals from EPR 9-10 $\mathrm{N}$, EPR $13^{\circ} \mathrm{N}$, and MAR $37^{\circ} \mathrm{N}$ would reflect incomplete isotope exchange between $\mathrm{H}_{2} \mathrm{~S}$ and $\mathrm{SO}_{4}$. The intersecting point between the $\delta^{34} \mathrm{~S}-\Delta^{33} \mathrm{~S}$ regression lines and the anhydrite buffer model line would indicate the temperature of isotope exchange (Figure 1). Such analyses for sulfide minerals from EPR 9-10 $\mathrm{N}$ and EPR $13^{\circ} \mathrm{N}$ suggest an isotope exchange temperature of $\sim 300^{\circ} \mathrm{C}$, whereas the derived temperature is slightly lower $\left(\sim 290^{\circ} \mathrm{C}\right)$ for a marcasite-sphalerite pair from the Lucky Strike vent field (Figure 1). The actual precipitation temperature of the marcasite, however, is thought to be much lower than $290^{\circ} \mathrm{C}$ based on temperatures measured at the seafloor vent (Rouxel et al., 2004).

At EPR $9-10^{\circ} \mathrm{N}$, the temperature of exchange derived from chimney wall sulfide minerals is about $300^{\circ} \mathrm{C}$, whereas a higher temperature (about $400^{\circ} \mathrm{C}$ ) is derived from vent $\mathrm{H}_{2} \mathrm{~S}$. This may reflect a temperature difference between fluids in the central conduit and sites in the chimney wall where metal sulfide minerals precipitate. Such steep temperature gradients are reasonably expected within the hydrothermal chimney walls, which have cold ambient seawater 
outside of the wall (Tivey, 1995). The difference in estimated temperatures, in this case, suggests isotope exchange among sulfide minerals is local and occurring either in the shallow subsurface or within chimney walls. Sulfur isotope exchange kinetics in the aqueous phase are slow at $300^{\circ} \mathrm{C}$, considering the residence time of fluid within the chimney wall, and takes 6 to 140 days at $\mathrm{pH}$ between 3 and 4 (90\% exchange for total $\mathrm{S}$ of $10 \mathrm{mmol} / \mathrm{kg}$, Ohmoto and Lasaga, 1982). It is possible that isotope exchange is faster in natural system when it is catalyzed by mineral surfaces.

Following the two-stage model, the intersecting point between the $\delta^{34} \mathrm{~S}-\Delta^{33} \mathrm{~S}$ regression lines for sulfide minerals and the two component mixing model line reflects the isotope composition of the deep $\mathrm{H}_{2} \mathrm{~S}$, and thus, the contribution of seawater-derived sulfate in vent sulfides (Figure 1). This conclusion allows calculation of the contents of seawater-derived sulfate, which are $17,12,22$, and $27 \%$ for sulfur at EPR $9-10^{\circ} \mathrm{N}, 13^{\circ} \mathrm{N}, 21^{\circ} \mathrm{S}$, and MAR $37^{\circ}$ $\mathrm{N}$, respectively (Figure 1). These data suggest contributions of seawater-derived sulfate could be relatively smaller at the northern EPR than at the SEPR and MAR, but much more data are needed to draw conclusions about geographic variations. Systematic analyses of $\delta^{34} \mathrm{~S} v \mathrm{vs} . \Delta^{33} \mathrm{~S}$ of sulfide minerals at various sites along mid-oceanic ridge vent systems may reveal differences in the subseafloor sulfur cycle, which must be related to the subsurface structure of hydrothermal circulation.

\subsection{Contribution of biological sulfate reduction in hydrothermal systems}

Microbial sulfate reduction by thermophilic Archea (Archeaeoglobus fulgidus) and sulfate reducing bacteria (Desulfospira jorgensenii and Desulfobacterium autotrophicum) is characterized by ${ }^{33} \theta$ values between 0.510 and 0.513 (Farquhar et al., 2003; Johnston et al., 
2005a). According to the flow-network model of Farquhar et al. (2003), the ${ }^{33} \theta$ values for microbial sulfate reduction can vary between 0.510 and 0.515 , depending upon the relative rates of forward and backward reactions in each enzymatic step. The $\Delta^{33} \mathrm{~S}^{*}$ values of biogenic sulfide reported in Ono et al. (2006) are higher than seawater sulfate, and plot between fractionation lines defined by ${ }^{33} \theta=0.515$ and ${ }^{33} \theta=0.512$, consistent with the experimental calibration by Farquhar et al. (2003) and Johnston et al. (2005a) (Figure 4). The $\Delta^{33} S$ values of seafloor hydrothermal sulfides measured in this study, in contrast, plot lower than the anhydrite buffered line $\left({ }^{33} \theta=0.515 \pm 0.0005\right)$ (Figure 4). This indicates no or undetectably small contribution of biogenic sulfide (i.e., sulfide derived from seawater sulfate via microbial sulfate reduction) into chimney sulfides and fluid $\mathrm{H}_{2} \mathrm{~S}$ in studied vent sites. This may be characteristic to the vent sites along sediment-free ridge systems.

Vent sulfides at sediment-covered ridge systems, in contrast, may carry signatures of biogenic sulfide from introduction of sulfide from overlying sediments. In these sedimentcovered sites, the multiple-sulfur isotope system can be used as a powerful tool to detect contribution of sedimentary-sulfide into hydrothermal vent sulfides even when their $\delta^{34} S$ values provide non-unique solution. Another potential applications include microbial sulfur cycle in hydrothermally heated sediments (Jorgensen et al., 1992), hydrothermal vent chimneys (Schrenk et al., 2003), and altered oceanic basement (Alt, 1995b; Bach and Edwards, 2003). Highprecision S-33 analysis may provide new constraints by uniquely distinguishing biological isotope fractionation processes from those caused by abiological (e.g, hydrothermal, isotope mixing) processes. 


\section{CONCLUSIONS}

We report results of measurements of all three stable isotope ratios of sulfur $\left(\delta^{33} \mathrm{~S}, \delta^{34} \mathrm{~S}\right.$ and $\delta^{36} \mathrm{~S}$ ) for four active high-temperature seafloor hydrothermal vents along sediment-free ridge systems. The use of both $\delta^{34} \mathrm{~S}$ and $\Delta^{33} \mathrm{~S}$ values indicates two major controls over multipleisotope compositions of sulfide: (1) the mixing ratio of seawater sulfate reduced in the deep high temperature reaction zone to basalt derived sulfides, and (2) the degree of sulfur isotope exchange between hydrothermal sulfide and sulfate though entrainment of seawater and dissolution of previously precipitated anhydrite. The $\Delta^{33} \mathrm{~S}$ and $\delta^{34} \mathrm{~S}$ systematics of vent $\mathrm{H}_{2} \mathrm{~S}$ from EPR $9-10^{\circ} \mathrm{N}$ suggest isotope exchange between sulfate and sulfide at about $400^{\circ} \mathrm{C}$ during upflow through a shallow anhydrite bearing zone. Mineral pairs, pyrite (and marcasite), sphalerite and chalcopyrite, are found to be in isotope disequilibrium not only in $\delta^{34} \mathrm{~S}$ but also in $\Delta^{33} \mathrm{~S}$. This suggests incomplete isotope exchange between $\mathrm{H}_{2} \mathrm{~S}$ and $\mathrm{SO}_{4}$ at temperature of $\sim 300^{\circ}$ C. Biogenic sulfide is characterized by relatively high $\Delta^{33} \mathrm{~S}$ values compared to seafloor hydrothermal sulfide. The $\delta^{34} \mathrm{~S}$ vs. $\Delta^{33} \mathrm{~S}$ systematics, therefore, can decouple microbial sulfur cycling at the ocean crust-seawater interfaces even when conventional $\delta^{34} S$ values themselves lead to non-unique interpretations. We conclude from these applications that analysis of nontraditional sulfur isotopes $\left({ }^{33} \mathrm{~S}\right.$ and $\left.{ }^{36} \mathrm{~S}\right)$ can be applied to constrain a broad range of long standing problems in sulfur isotope geochemistry and biogeochemistry. 


\section{Acknowledgements}

S. Ono thanks the Agouron Institute for financial support, J. Voight for providing sulfide samples from EPR $13^{\circ} \mathrm{N}$ and Y. Fouquet (IFEMER) for samples from the Lucky Strike hydrothermal field, and funding from the NASA Astrobiology Institute and Carnegie Institution of Washington for supporting the analytical costs. S. Ono also acknowledges J. Farquhar and B. Wing for their generous inputs that made high-precision $\mathrm{SF}_{6}$ analysis at Geophysical Laboratory possible. Funding for O. Rouxel is from the Deep Ocean Exploration Institute at WHOI. Authors also acknowledge P. Morrill, M. Fogel, R. Rye, G. Landis, and C. Johnson for their constructive comments for earlier versions of the manuscripts, and B. Wing, R. Seal, M. Mottl, and J. Horita for helpful reviews, all of which greatly improved the manuscript. 


\section{References}

Alt J. C. (1995a) Subseafloor processes in mid-ocean ridge hydrothermal systems. Geophysical Monograph 91, 85-114.

Alt J. C. (1995b) Sulfur isotopic profile through the oceanic crust: Sulfur mobility and seawatercrustal sulfur exchange during hydrothermal alteration. Geology 23, 585-588

Alt J. C., Shanks W. C., III, and Jackson M. C. (1993) Cycling of sulfur in subduction zones; the geochemistry of sulfur in the Mariana island arc and back-arc trough. Earth Planet. Sci. Lett. 119, 477-494.

Angert A., Cappa C. D., and DePaolo D. J. (2004) Kinetic O-17 effects in the hydrologic cycle: Indirect evidence and implications. Geochim. Cosmochim. Acta 68, 3487-3495.

Assonov S. S. and Brenninkmeijer C. A. (2005) Reporting small $\Delta^{17}$ O values: existing definitions and concepts. Rapid Commun. Mass Spectrom. 19, 627-636.

Bach W. and Edwards K. J. (2003) Iron and sulfide oxidation within the basaltic ocean crust; implications for chemolithoautotrophic microbial biomass production. Geochim. Cosmochim. Acta 67, 3871-3887

Benning L. G., Wilkin R. T., and Barnes H. L. (2000) Reaction pathways in the Fe-S system below $100^{\circ}$ C. Chem. Geol. 167, 25-51.

Bischoff, J.L., and Rosenbauer, R.J., 1988, Liquid-vapor relations in the critical region of the system sodium chloride-water from 380 to $415^{\circ} \mathrm{C}$ : A refined determination of the critical point and two-phase boundary of seawater. Geochim. Cosmochim. Acta 52, 2121-2126.

Bluth G. and Ohmoto H. (1988) Sulfide-sulfate chimneys on the East Pacific Rise, $11^{\circ}$ and $13^{\circ} \mathrm{N}$ latitudes, Part II: Sulfur isotopes. Can. Mineral. 26, 505-515. 
Broecker W.S. and Peng, T-H (1982) Tracers in the sea. Lamont-Doherty Geol. Obs., Palisades, NY. 690 pp.

Charlou J. L., Donval J. P., Douville E., Jean-Baptiste P., Radford-Knoery J., Fouquet Y., Dapoigny A., and Stievenard M. (2000) Compared geochemical signatures and the evolution of Menez Gwen (37 $\left.50^{\prime} \mathrm{N}\right)$ and Lucky Strike $\left(37^{\circ} 17^{\prime} \mathrm{N}\right)$ hydrothermal fluids, south of the Azores triple junction on the Mid-Atlantic Ridge. Chem. Geol. 171, 49-75.

Elderfield H. and Schultz A. (1996) Mid-ocean ridge hydrothermal fluxes and the chemical composition of the ocean. Annu. Rev. Earth Planet. Sci. 24, 191-224

Farquhar J., Bao H., and Thiemens M. (2000a) Atmospheric influence of Earth's earliest sulfur cycle. Science $\mathbf{2 8 9}, \mathbf{7 5 6 - 9 .}$

Farquhar J., Jackson T. L., and Thiemens M. H. (2000b) A S-33 enrichment in ureilite meteorites: Evidence for a nebular sulfur component. Geochim. Cosmochim. Acta 64, 1819-1825.

Farquhar J., Savarino J., Jackson T. L., and Thiemens M. H. (2000c) Evidence of atmospheric sulphur in the martian regolith from sulphur isotopes in meteorites. Nature 404, 50-52.

Farquhar J. and Wing B. A. (2005) Sulfur multiple isotopes of the Moon: 33S and 36S abundances relative to Canon Diablo Troilite. Proeedings of the Lunar and Planetary Science, XXXVI, 2380.

Farquhar J., Wing B. A., McKeegan K. D., Harris J. W., Cartigny P., and Thiemens M. H. (2002) Mass-independent sulfur of inclusions in diamond and sulfur recycling on early earth. Science 298, 2369-2372. 
Farquhar J., Johnston D. T., Wing B. A., Habicht K. S., Canfield D. E., Airieau S., and Thiemens M. H. (2003) Multiple sulphur isotopic interpretations of biosynthetic pathways; implications for biological signatures in the sulphur isotope record. Geobiology 1, 27-36.

Fisher, A.T., 2004, Rates of flow and patterns of fluid circulation, In Hydrogeology of the Oceanic Lithosphere. (eds. Davis, E.E., and Elderfield, H.) Cambridge University Press, Cambridge, U.K., p. 337-375.

Gao X. and Thiemens M. H. (1991) Systematic study of sulfur isotopic composition in iron meteorites and the occurrence of excess ${ }^{33} \mathrm{~S}$ and ${ }^{36} \mathrm{~S}$. Geochim. Cosmochim. Acta 55, 2671-2679.

Gao X. and Thiemens M. H. (1993a) Isotopic composition and concentration of sulfur in carbonaceous chondrites. Geochimica et Cosmochimica Acta 57, 3159-3169.

Gao X. and Thiemens M. H. (1993b) Variations of the isotopic composition of sulfur in enstatite and ordinary chondrites. Geochim. Cosmochim. Acta 57, 3171-3176.

Garrels R. M. and Lerman A. (1981) Phanerozoic cycles of sedimentary carbon and sulfur. Proc. Nat. Acad. Sci. 78, 4652-4656.

Holser W. T., Maynard J. B., and Cruikshank K. M. (1989) Modeling the natural cycle of sulphur through Phanerozoic time. In Evolution of the global biogeochemical sulphur cycle (ed. P. Brimblecombe and A. Y. Lein), pp. 21-56. Wiley.

Hu G. X., Rumble D., and Wang P. L. (2003) An ultraviolet laser microprobe for the in situ analysis of multisulfur isotopes and its use in measuring Archean sulfur isotope massindependent anomalies. Geochim. Cosmochim. Acta 67, 3101-3118.

Hulston J. R. and Thode H. G. (1965) Variations in the $\mathrm{S}^{33}, \mathrm{~S}^{34}$, and $\mathrm{S}^{36}$ contents of meteorites and their relation to chemical and nuclear effects. J. Geophy. Res. 70, 3475-3484. 
Humphris S. E. and Tivey M. K. (2000) A synthesis of geological and geochemical investigations of the TAG hydrothermal field; insights into fluid-flow and mixing processes in a hydrothermal system. Special Paper-Geol. Soc. Amer. 349, 213-235.

Janecky D. R. and Shanks W. C., III. (1988) Computational modeling of chemical and sulfur isotopic reaction processes in seafloor hydrothermal systems: chimneys, massive sulfides, and subjacent alteration zones. Can. Mineral. 26, 805-825.

Johnston D. T., Farquhar J., Wing B. A., Kaufman A. J., Canfield D. E., and Habicht K. S. (2005a) Multiple sulfur isotope factionations in biological systems: a case study with sulfate reducers and sulfur disproportionators. Amer. J. Sci. 305, 645-660.

Johnston D. T., Wing B. A., Farquhar J., Kaufman A. J., Strauss H., Lyons T. W., Kah L. C., and Canfield D. E. (2005b) Active microbial sulfur disproportionation in the Mesoproterozoic. Science 310, 1477-1479.

Jorgensen B. B., Isaksen M. F., and Jannasch H. W. (1992) Bacterial sulfate reduction above $100^{\circ} \mathrm{C}$ in deep-sea hydrothermal vent sediments. Science 258, 1756-1757.

Kadko D., Baross J., and Alt J. C. (1995) The magnitude and global implications of hydrothermal flux. Geophysical Monograph 91, 446-466.

Kaiser J., Rockmann T., and Brenninkmeijer C. A. M. (2004) Contribution of mass-dependent fractionation to the oxygen isotope anomaly of atmospheric nitrous oxide - art. no. D03305. J. Geophy. Res. 109, doi:10.1029/2003JD004088.

Kerridge J. F., Haymon R. M., and Kastner M. (1983) Sulfur isotope systematics at the $21^{\circ} \mathrm{N}$ site, East Pacific Rise. Earth Planet. Sci. Lett. 66, 91-100. 
Kusakabe M., Mayeda S., Nakamura E., and Anonymous. (1990) S, O And Sr isotope systematics of active vent materials from the Mariana backarc basin spreading axis at 18 degrees N. Earth Planet. Sci. Lett. 100, 275-282.

Luz B., Barkan E., Bender M. L., Thiemens M. H., and Boering K. A. (1999) Triple-isotope composition of atmospheric oxygen as a tracer of biosphere productivity. Nature $\mathbf{4 0 0}$, 547-550.

Matsuhisa Y., Goldsmith J. R., and Clayton R. N. (1978) Mechanisms of hydrothermal crystallization of quartz at $250^{\circ} \mathrm{C}$ and 15 kbars. Geochim. Cosmochim. Acta 42, 173-182.

Miller M. F. (2002) Isotopic fractionation and the quantification of ${ }^{17} \mathrm{O}$ anomalies in the oxygen three-isotope system; an appraisal and geochemical significance. Geochim. Cosmochim. Acta 66, 1881-1889.

Mottl M. J., Holland H. D., and Corr R. F. (1979) Chemical exchange during hydrothermal alteration of basalt by seawater; II, Experimental results for Fe, Mn, and sulfur species. Geochim. Cosmochim. Acta 43, 869-884.

Nakamoto K. (1997) Infrared and raman spectra of inorganic and coordination compounds. John Willy \& Sons, Inc. pp. 484

Ohmoto H. and Goldhaber M. B. (1997) Sulfur and carbon isotopes. In Geochemistry of hydrothermal ore deposits (ed. H. L. Barnes). John Wiley \& Sons.

Ohmoto H. and Lasaga A. C. (1982) Kinetics of reactions between aqueous sulfates and sulfides in hydrothermal systems. Geochim. Cosmochim. Acta 46, 1727-1745.

Ohmoto H., Mizukami M., Drummond S. E., Eldridge C. S., Pisutha-Arnond V., and Lenagh T. C. (1983) Chemical processes of kuroko formation. Economic Geology Monographs $\mathbf{5}$, 570-604. 
Ono S., Eigenbrode J. L., Pavlov A. A., Kharecha P., Rumble D., Kasting J. F., and Freeman K. H. (2003) New insights into Archean sulfur cycle from mass-independent sulfur isotope records from the Hamersley Basin, Australia. Earth Planet. Sci. Lett. 213, 15-30.

Ono S., Wing B. A., Johnston D., Farquhar J., and Rumble D. (2006) Mass-dependent fractionation of quadruple sulfur isotope system as a new tracer of sulfur biogeochemical cycles. Geochim. Cosmochim. Acta 70, 2238-2252.

Rees C. E., Jenkins W. J., Monster J. (1978) The sulphur isotopic composition of ocean water sulphate. Geochim. Cosmochim. Acta 42, 377-382

Rickard D. (1997) Kinetics of pyrite formation by the $\mathrm{H}_{2} \mathrm{~S}$ oxidation of iron (II) monosulfide in aqueous solutions between 25 and $125^{\circ} \mathrm{C}$; the rate equation. Geochim. Cosmochim. Acta 61, 115-134.

Robinson B. W. (1993) Sulphur isotope standard. In Reference and intercomparison materials for stable isotopes of light elements, Vol. IAEA-TECHDOC-825, pp. 39-45. IAEA.

Rouxel O., Fouquet Y., and Ludden J. N. (2004) Subsurface processes at the Lucky Strike hydrothermal field, Mid-Atlantic Ridge; evidence from sulfur, selenium, and iron isotopes. Geochim. Cosmochim. Acta 68, 2295-2311.

Sakai H. (1968) Isotopic properties of sulfur compounds in hydrothermal processes. Geochem. J. 2, 29-49.

Sakai H., Casadevall T. J., and Moore J. G. (1982) Chemistry and isotope ratios of sulfur in basalts and volcanic gases at Kilauea Volcano, Hawaii. Geochim. Cosmochim. Acta 46, 729-738. 
Sakai H., Des Marais D. J., Ueda A., and Moore J. G. (1984) Concentrations and isotope ratios of carbon, nitrogen and sulfur in ocean-floor basalts. Geochim. Cosmochim. Acta 48, 2433-2441.

Schauble E. A. (2004) Applying stable isotope fractionation theory to new systems. Rev. Mineral. Geochem. 55, 65-111.

Schoonen M. A. A. (2004) Mechanisms of sedimentary pyrite formation. Special Paper-Geol. Soc. Amer. 379, 117-134.

Schoonen M. A. A. and Barnes H. L. (1991) Mechanisms of pyrite and marcasite formation from solution; III, Hydrothermal processes. Geochim. Cosmochim. Acta 55, 3491-3504.

Schrenk M. O., Kelley D. S., Delaney J. R., and Baross J. A. (2003) Incidence and diversity of microorganisms within the walls of an active deep-sea sulfide chimney. Appl. Environ. Microbiol. 69, 3580-3592.

Seal R. R., II, Alpers C. N., and Rye R. O. (2000) Stable isotope systematics of sulfate minerals. Rev. Mineral. Geochem. 40, 541-602.

Seyfried W. E., Jr. and Ding K. (1995) Phase equilibria in subseafloor hydrothermal systems; a review of the role of redox, temperature, $\mathrm{pH}$ and dissolved $\mathrm{Cl}$ on the chemistry of hot spring fluids at mid-ocean ridges. Geophysical Monograph 91, 248-272.

Seyfried W. E., Jr. and Shanks W. C., III. (2004) Alteration and mass transport in mid-ocean ridge hydrothermal systems: controls on the chemical and isotopic evolution of hightemperature crustal fluids. In Hydrogeology of the Oceanic Lithosphere (ed. E. E. Davis and H. Elderfield), pp. 453-496. Cambridge University Press. 
Shanks W. C., III. (2001) Stable isotopes in seafloor hydrothermal systems; vent fluids, hydrothermal deposits, hydrothermal alteration, and microbial processes. Rev. Mineral. Geochem. 43, 469-525.

Shanks W. C., III, Bischoff J. L., and Rosenbauer R. J. (1981) Seawater sulfate reduction and sulfur isotope fractionation in basaltic systems; interaction of seawater with fayalite and magnetite at 200-350 C. Geochim. Cosmochim. Acta 45, 1977-1995.

Shanks W. C., III, Bohlke J. K., and Seal R. R., II. (1995) Stable isotopes in mid-ocean ridge hydrothermal systems; interactions between fluids, minerals, and organisms. Geophysical Monograph 91, 194-221.

Shanks W. C., III and Seyfried W. E., Jr. (1987) Stable isotope studies of vent fluids and chimney minerals, southern Juan de Fuca Ridge; sodium metasomatism and seawater sulfate reduction. J. Geophy. Res. B 92, 11,387-11,399.

Sleep N. H. (1991) Hydrothermal circulation, anhydrite precipitation, and thermal structure at ridge axes. J. Geophy. Res. B 96, 2375-2387.

Stein C. A. and Stein S. (1994) Constraints on hydrothermal heat flux through the oceanic lithosphere from global heat flow. J. Geophy. Res. B 99, 3081-3095.

Tivey M. K. (1995) Modeling chimney growth and associated fluid flow at seafloor hydrothermal vent sites. Geophysical Monograph 91, 158-177.

Urey H. C. (1947) The thermodynamic properties of isotopic substances. J. Chem. Soc. 562-581. Von Damm K. L. (2000) Chemistry of hydrothermal vent fluids from $9^{\circ}-10^{\circ} \mathrm{N}$, East Pacific Rise; "time zero," the immediate posteruptive period. J. Geophy. Res. B 105, 1120311222. 
Von Damm K. L., Bray A. M., Buttermore L. G., and Oosting S. E. (1998) The geochemical controls on vent fluids from the Lucky Strike vent field, Mid-Atlantic Ridge. Earth Planet. Sci. Lett. 160, 521-536.

Von Damm K. L., Lilley M. D., Shanks W. C., III, Brockington M., Bray A. M., O'Grady K. M., Olson E., Graham A., Proskurowski G., Collier R., Cowen J., Haymon R., Tivey M. K., Fornari D., Nakamura K., McLaughlin-West E., Shank T., Kaye J., Hobson J., Sarrazin J., Sparrow M., Hubbard D., McGee D., Brinson S., and Cushman B. (2003) Extraordinary phase separation and segregation in vent fluids from the southern East Pacific Rise. Earth Planet. Sci. Lett. 206, 365-378.

Wilkin R. T. and Barnes H. L. (1996) Pyrite formation by reactions of iron monosulfides with dissolved inorganic and organic sulfur species. Geochim. Cosmochim. Acta 60, 41674179.

Woodruff L. G. and Shanks W. C., III. (1988) Sulfur isotope study of chimney minerals and vent fluids from $21^{\circ} \mathrm{N}$, East Pacific Rise; hydrothermal sulfur sources and disequilibrium sulfate reduction. J. Geophy. Res. B 93, 4562-4572.

Young E. D., Galy A., and Nagahara H. (2002) Kinetic and equilibrium mass-dependent isotope fractionation laws in nature and their geochemical and cosmochemical significance. Geochim. Cosmochim. Acta 66, 1095-1104. 


\section{TABLES}

Table 1: Sulfur isotope composition of reference materials with respect to working reference gas.

*: in-situ analysis of CDT by a $\mathrm{KrF}$ excimer laser

$\dagger$ : analyses of $\mathrm{Ag}_{2} \mathrm{~S}$ made from CDT, not identical with the one analyzed by in-situ.

\# : $1 \sigma$ derived for dual-inlet mass-spectrometry analysis that consists of three to five runs.

$\S: \Delta^{33} S$ values are calculated for each run and averaged. $1 \sigma$ are often smaller than those for $\delta^{33} S$ and $\delta^{34} \mathrm{~S}$ because of the correlated errors in $\delta^{33} \mathrm{~S}$ and $\delta^{34} \mathrm{~S}$.

\begin{tabular}{|c|c|c|c|c|c|c|c|c|c|c|}
\hline Samples & $\delta^{33} \mathrm{~S}$ & $\pm 1 \sigma^{\ddagger}$ & $\delta^{34} \mathrm{~S}$ & $\pm 1 \sigma^{\ddagger}$ & $\delta^{36} \mathrm{~S}$ & $\pm 1 \sigma^{\ddagger}$ & $\Delta^{33} \mathrm{~S}^{\S}$ & $\pm 1 \sigma^{\S}$ & $\Delta^{36} \mathrm{~S}^{\S}$ & $\pm 1 \sigma^{\S}$ \\
\hline CDT-2* & 2.045 & 0.013 & 4.030 & 0.010 & 7.49 & 0.08 & -0.030 & 0.013 & -0.17 & 0.06 \\
\hline CDT-2* & 2.105 & 0.009 & 4.180 & 0.008 & 7.86 & 0.05 & -0.048 & 0.006 & -0.08 & 0.04 \\
\hline CDT-2* & 2.129 & 0.015 & 4.176 & 0.009 & 7.93 & 0.04 & -0.022 & 0.011 & 0.00 & 0.02 \\
\hline average & 2.093 & & 4.129 & & 7.76 & & -0.033 & & -0.08 & \\
\hline $1 \sigma$ & 0.043 & & 0.086 & & 0.24 & & 0.013 & & 0.08 & \\
\hline CDT $-3^{\dagger}$ & 1.853 & 0.006 & 3.687 & 0.014 & 6.88 & 0.07 & -0.046 & 0.006 & -0.12 & 0.06 \\
\hline CDT $-3^{\dagger}$ & 1.778 & 0.017 & 3.550 & 0.030 & 6.63 & 0.05 & -0.050 & 0.007 & -0.11 & 0.07 \\
\hline $\mathrm{CDT}_{-} 3^{\dagger}$ & 1.793 & 0.020 & 3.589 & 0.016 & 6.64 & 0.14 & -0.056 & 0.014 & -0.18 & 0.12 \\
\hline average & 1.808 & & 3.608 & & 6.72 & & -0.051 & & -0.14 & \\
\hline $1 \sigma$ & 0.040 & & 0.071 & & 0.14 & & 0.005 & & 0.03 & \\
\hline IAEA S-1 & 1.986 & 0.003 & 3.737 & 0.003 & 6.21 & 0.07 & 0.061 & 0.003 & -0.89 & 0.07 \\
\hline IAEA S-1 & 2.138 & 0.009 & 4.037 & 0.007 & 6.89 & 0.05 & 0.058 & 0.007 & -0.78 & 0.05 \\
\hline IAEA S-1 & 2.330 & 0.009 & 4.414 & 0.007 & 7.58 & 0.15 & 0.057 & 0.006 & -0.81 & 0.15 \\
\hline IAEA S-1 & 2.052 & 0.007 & 3.863 & 0.008 & 6.60 & 0.08 & 0.063 & 0.006 & -0.74 & 0.08 \\
\hline IAEA S-1 & 1.966 & 0.010 & 3.689 & 0.012 & 6.17 & 0.07 & 0.066 & 0.006 & -0.84 & 0.07 \\
\hline IAEA S-1 & 1.969 & 0.012 & 3.710 & 0.020 & 6.23 & 0.08 & 0.058 & 0.009 & -0.82 & 0.10 \\
\hline IAEA S-1 & 2.216 & 0.006 & 4.187 & 0.006 & 6.88 & 0.05 & 0.060 & 0.007 & -1.08 & 0.05 \\
\hline IAEA S-1 & 1.994 & 0.005 & 3.760 & 0.005 & 6.23 & 0.18 & 0.058 & 0.006 & -0.91 & 0.17 \\
\hline average & 2.081 & & 3.925 & & 6.60 & & 0.060 & & -0.86 & \\
\hline $1 \sigma$ & 0.135 & & 0.264 & & 0.50 & & 0.003 & & 0.10 & \\
\hline NBS OGS-1 & 12.991 & 0.012 & 25.365 & 0.007 & 48.41 & 0.07 & -0.072 & 0.011 & 0.22 & 0.06 \\
\hline NBS OGS-1 & 13.011 & 0.006 & 25.399 & 0.004 & 48.50 & 0.07 & -0.069 & 0.006 & 0.24 & 0.07 \\
\hline NBS OGS-1 & 13.059 & 0.009 & 25.489 & 0.006 & 48.73 & 0.11 & -0.068 & 0.011 & 0.30 & 0.11 \\
\hline average & 13.020 & & 25.418 & & 48.55 & & -0.070 & & 0.25 & \\
\hline $1 \sigma$ & 0.035 & & 0.064 & & 0.16 & & 0.002 & & 0.04 & \\
\hline
\end{tabular}


Table 2: Isotope composition of reference materials with respect to VCDT scale. Bold figures represent defined values (see text). Values are from this study (Table 1) and Ono et al. (2006). Uncertainties are $1 \sigma$.

*: numbers of analyses are in parentheses.

$\dagger$ : from Ono et al. (2006)

‡: from Table 1

\begin{tabular}{|c|c|c|c|c|c|}
\hline ID $^{*}$ & $\delta^{33} \mathrm{~S}$ & $\delta^{34} \mathrm{~S}$ & $\delta^{36} S$ & $\Delta^{33} S$ & $\Delta^{36} \mathrm{~S}$ \\
\hline CDT-1 (7) ${ }^{\dagger}$ & $0.019 \pm 0.16$ & $0.050 \pm 0.30$ & $0.20 \pm 0.64$ & $-0.007 \pm 0.013$ & $0.11 \pm 0.17$ \\
\hline CDT-2 $(3)^{\ddagger}$ & $-0.043 \pm 0.04$ & $-0.097 \pm 0.09$ & $-0.21 \pm 0.24$ & $0.007 \pm 0.013$ & $-0.03 \pm 0.08$ \\
\hline $\operatorname{CDT}-3(3)^{\ddagger}$ & $-0.326 \pm 0.04$ & $-0.616 \pm 0.07$ & $-1.25 \pm 0.14$ & $-0.009 \pm 0.005$ & $-0.08 \pm 0.03$ \\
\hline IAEA S-1 $(8)^{\ddagger}$ & $\mathbf{- 0 . 0 5 5} \pm 0.14$ & $\mathbf{- 0 . 3 0 0} \pm 0.26$ & $\mathbf{- 1 . 3 7} \pm 0.50$ & $\mathbf{0 . 1 0 0} \pm 0.003$ & $\mathbf{- 0 . 8 0} \pm 0.10$ \\
\hline IAEA S-2 $(3)^{\dagger}$ & $11.282 \pm 0.15$ & $21.923 \pm 0.29$ & $41.83 \pm 0.52$ & $-0.009 \pm 0.003$ & $0.17 \pm 0.05$ \\
\hline IAEA S-3 $(5)^{\dagger}$ & $-16.716 \pm 0.25$ & $-32.360 \pm 0.47$ & $-61.70 \pm 0.67$ & $-0.050 \pm 0.004$ & $-0.21 \pm 0.25$ \\
\hline OGS-1 (3) & $10.860 \pm 0.04$ & $21.102 \pm 0.06$ & $40.68 \pm 0.16$ & $-0.007 \pm 0.002$ & $0.59 \pm 0.04$ \\
\hline
\end{tabular}


Table 3: Multiple-sulfur isotope compositions of modern hydrothermal sulfide normalized to VCDT scale. py: pyrite, cpy: chalcopyrite, mar: marcasite, and sph: sphalerite. Samples for 9$10^{\circ} \mathrm{N}$ EPR are vent $\mathrm{H}_{2} \mathrm{~S}$ and chimney-wall metal sulfides (MeS) that are converted to $\mathrm{Ag}_{2} \mathrm{~S}$ for fluorination analysis.

\begin{tabular}{|c|c|c|c|c|c|c|c|c|c|c|}
\hline Samples & $\delta^{33} \mathrm{~S}$ & $\pm 1 \sigma$ & $\delta^{34} \mathrm{~S}$ & $\pm 1 \sigma$ & $\delta^{36} \mathrm{~S}$ & $\pm 1 \sigma$ & $\Delta^{33} \mathrm{~S}$ & $\pm 1 \sigma$ & $\Delta^{36} \mathrm{~S}$ & $\pm 1 \sigma$ \\
\hline \multicolumn{11}{|l|}{$\operatorname{EPR} 9-10^{\circ} \mathrm{N}$} \\
\hline $2736-12$ vent $\mathrm{H}_{2} \mathrm{~S}$ & 2.311 & 0.010 & 4.435 & 0.016 & 8.58 & 0.12 & 0.027 & 0.005 & 0.15 & 0.11 \\
\hline 2736-3-4 -MeS & 1.356 & 0.015 & 2.634 & 0.022 & 4.83 & 0.08 & 0.000 & 0.010 & -0.17 & 0.08 \\
\hline $2748-14$ vent $\mathrm{H}_{2} \mathrm{~S}$ & 2.415 & 0.008 & 4.674 & 0.008 & 9.01 & 0.04 & 0.008 & 0.006 & 0.13 & 0.05 \\
\hline 2748-6-2-MeS & 1.789 & 0.012 & 3.471 & 0.036 & 6.64 & 0.08 & 0.001 & 0.007 & 0.04 & 0.04 \\
\hline $2752-11$ vent $\mathrm{H}_{2} \mathrm{~S}$ & 3.031 & 0.008 & 5.849 & 0.011 & 11.12 & 0.09 & 0.019 & 0.005 & 0.01 & 0.08 \\
\hline 2752-4-7-MeS & 1.698 & 0.012 & 3.288 & 0.004 & 6.21 & 0.11 & 0.004 & 0.011 & -0.04 & 0.11 \\
\hline 2756-14 vent $\mathrm{H}_{2} \mathrm{~S}$ & 2.530 & 0.015 & 4.825 & 0.017 & 9.19 & 0.09 & 0.045 & 0.010 & 0.03 & 0.07 \\
\hline 2756-4-2-MeS & 0.713 & 0.014 & 1.341 & 0.011 & 2.26 & 0.07 & 0.022 & 0.010 & -0.29 & 0.08 \\
\hline \multicolumn{11}{|l|}{$\operatorname{EPR} 13^{\circ} \mathrm{N}$} \\
\hline 3938 py & 0.301 & 0.016 & 0.525 & 0.018 & 0.89 & 0.08 & 0.031 & 0.008 & -0.10 & 0.06 \\
\hline 3938 py & 0.231 & 0.011 & 0.391 & 0.009 & 0.67 & 0.12 & 0.030 & 0.008 & -0.08 & 0.11 \\
\hline 3938 py & 0.502 & 0.011 & 0.925 & 0.012 & 1.77 & 0.19 & 0.026 & 0.007 & 0.01 & 0.18 \\
\hline 3938 py & 0.534 & 0.005 & 1.002 & 0.005 & 1.78 & 0.11 & 0.018 & 0.006 & -0.13 & 0.12 \\
\hline $3938 \mathrm{sph}$ & 1.124 & 0.012 & 2.18 & 0.019 & 4.14 & 0.04 & 0.001 & 0.010 & 0.00 & 0.06 \\
\hline $3938 \mathrm{sph}$ & 1.353 & 0.008 & 2.632 & 0.021 & 4.90 & 0.04 & -0.002 & 0.005 & -0.10 & 0.04 \\
\hline $3938 \mathrm{sph}$ & 1.068 & 0.009 & 2.046 & 0.004 & 3.95 & 0.08 & 0.014 & 0.009 & 0.06 & 0.09 \\
\hline \multicolumn{11}{|l|}{$E P R 21^{\circ} \mathrm{S}$} \\
\hline 3290-7-1b сру & 2.342 & 0.007 & 4.543 & 0.010 & 8.76 & 0.26 & 0.002 & 0.008 & 0.13 & 0.26 \\
\hline 3290-7-1b сру & 2.353 & 0.005 & 4.558 & 0.015 & 8.81 & 0.13 & 0.005 & 0.007 & 0.15 & 0.11 \\
\hline $3290-7-1 b$ sph & 2.742 & 0.010 & 5.307 & 0.029 & 9.94 & 0.12 & 0.009 & 0.012 & -0.14 & 0.11 \\
\hline $3290-7-1 b$ sph & 2.513 & 0.010 & 4.863 & 0.009 & 9.35 & 0.08 & 0.008 & 0.010 & 0.11 & 0.07 \\
\hline \multicolumn{11}{|c|}{ MAR $37^{\circ} N$, Lucky Strike vent field } \\
\hline FL 24-01 mar & -0.203 & 0.005 & -0.448 & 0.003 & -1.08 & 0.15 & 0.028 & 0.006 & -0.23 & 0.15 \\
\hline FL 24-01 cpy & 0.908 & 0.004 & 1.72 & 0.004 & 3.15 & 0.05 & 0.022 & 0.003 & -0.12 & 0.04 \\
\hline FL 24-02 mar & 0.270 & 0.018 & 0.46 & 0.035 & 0.62 & 0.12 & 0.033 & 0.010 & -0.25 & 0.12 \\
\hline FL 24-02 mar & -0.420 & 0.004 & -0.875 & 0.005 & -1.98 & 0.07 & 0.031 & 0.005 & -0.32 & 0.07 \\
\hline FL 29-02 сру & 1.852 & 0.017 & 3.584 & 0.018 & 6.79 & 0.08 & 0.007 & 0.008 & -0.02 & 0.04 \\
\hline
\end{tabular}


Table 4: Theoretical multiple-sulfur isotope fractionation factors between $\mathrm{SO}_{4}{ }^{2-}$ and $\mathrm{H}_{2} \mathrm{~S}$ as a function of temperature

\begin{tabular}{rccc}
$\mathrm{T}\left({ }^{\circ} \mathrm{C}\right)$ & $1000 \ln \left({ }^{34} \alpha\right)$ & ${ }^{33} \theta$ & ${ }^{36} \theta$ \\
\hline 0 & 78.4 & 0.5145 & 1.900 \\
50 & 59.8 & 0.5147 & 1.899 \\
100 & 46.9 & 0.5148 & 1.898 \\
150 & 37.6 & 0.5150 & 1.897 \\
200 & 30.7 & 0.5151 & 1.896 \\
250 & 25.5 & 0.5151 & 1.895 \\
300 & 21.5 & 0.5152 & 1.895 \\
350 & 18.3 & 0.5153 & 1.895 \\
400 & 15.8 & 0.5153 & 1.894 \\
450 & 13.7 & 0.5154 & 1.894 \\
500 & 12.0 & 0.5154 & 1.894 \\
1000 & 4.4 & 0.5156 & 1.893
\end{tabular}




\section{FIGURE CAPTIONS}

Figure 1: Plots of $\delta^{34} \mathrm{~S}$ versus $\Delta^{33} \mathrm{~S}$ for vent $\mathrm{H}_{2} \mathrm{~S}$ and chimney sulfide minerals measured in this study. (A) $9-10^{\circ} \mathrm{N}$ EPR, vent $\mathrm{H}_{2} \mathrm{~S}$ and bulk chimney-wall metal sulfides (chimney MeS), (B) $13^{\circ} \mathrm{N}$ EPR, (C) $21^{\circ} \mathrm{S}$ EPR, and (D) $37^{\circ} \mathrm{N}$ MAR, Lucky Strike vent field. Error bars represent $1 \sigma$ for dual-inlet mass-spectrometry measurements (Table 3$)$. Errors for $\delta^{34} \mathrm{~S}( \pm 0.3 \%$ ) are approximately equivalent to the size of symbols. Solid plain lines in A, B, and D are least squares fit for sulfide minerals. Also shown are the isotope compositions of end-member $\mathrm{H}_{2} \mathrm{~S}$ that are expected for the anhydrite buffer model (dashed line) and the two component mixing model (solid line with cross). The numbers on the anhydrite buffer model are isotope equilibrium temperatures and the crosses on the mixing model correspond to a mixing ratio in one-tenth increment (see text and Figure 2 for description).

Figure 2: The isotope composition of $\mathrm{H}_{2} \mathrm{~S}$ expected for the two component mixing (solid line) and anhydrite buffer (dashed line) models. BS and SW represent model isotope compositions of basaltic sulfide and seawater sulfate, respectively. The anhydrite buffer model shows the isotope composition of $\mathrm{H}_{2} \mathrm{~S}$ that is in isotope equilibrium with seawater sulfate as a function of temperature, and the two component mixing model represents mixing of basaltic sulfide and seawater sulfate. The two models are compared (A) in traditional $\delta^{34} \mathrm{~S}$ and $\Delta^{33} \mathrm{~S}$ coordinates, and (B) in modified $\delta^{34} \mathrm{~S}^{*}$ vs. $\Delta^{33} \mathrm{~S}^{*}$ coordinates (B).

Figure 3: Two stage model for hydrothermal vent sulfides for EPR 9-10 ${ }^{\circ} \mathrm{N}$. The isotope composition of sulfide sulfur in the deep reaction zone (deep $\left.\mathrm{H}_{2} \mathrm{~S}\right)$ follows the two component mixing model. During fluid upflow, isotope exchange between $\mathrm{H}_{2} \mathrm{~S}$ and $\mathrm{SO}_{4}$ at anhydrite bearing zone brings $\mathrm{H}_{2} \mathrm{~S}$ isotope compositions towards the anhydrite buffer line. Two model cases are shown when isotope exchange occurred at 300 and $400^{\circ} \mathrm{C}$ (A and $\mathrm{B}$, respectively). 
Figure 4: Comparison of hydrothermal sulfide and biological sulfide in (A) $\delta^{34} \mathrm{~S}$ vs. $\Delta^{33} \mathrm{~S}$ coordinates and in (B) $\delta^{34} \mathrm{~S}^{*}$ vs. $\Delta^{33} \mathrm{~S}^{*}$ coordinates. Hydrothermal sulfides plot between the mixing line between seawater sulfate (SW) and CDT and the fractionation line with ${ }^{33} \theta=0.515$, whereas biogenic pyrite samples plot between two fractionation lines $\left({ }^{33} \theta=0.515\right.$ and ${ }^{33} \theta=$ 0.512). Also shown are isotopic compositions of IAEA reference materials (S-1, S-2, and S-3). 


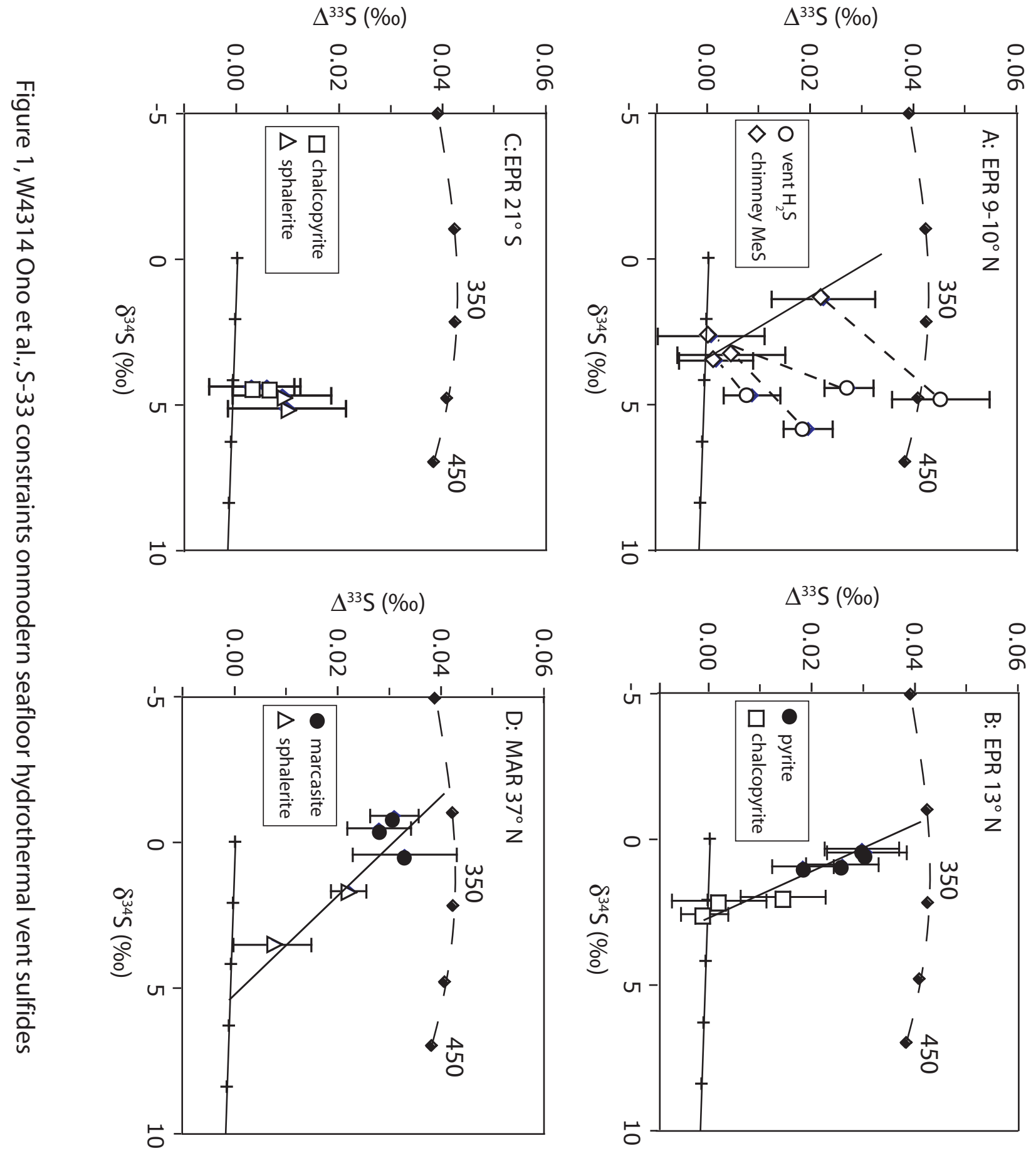




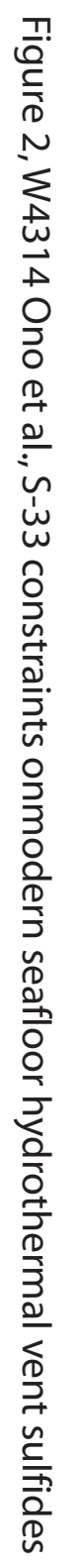
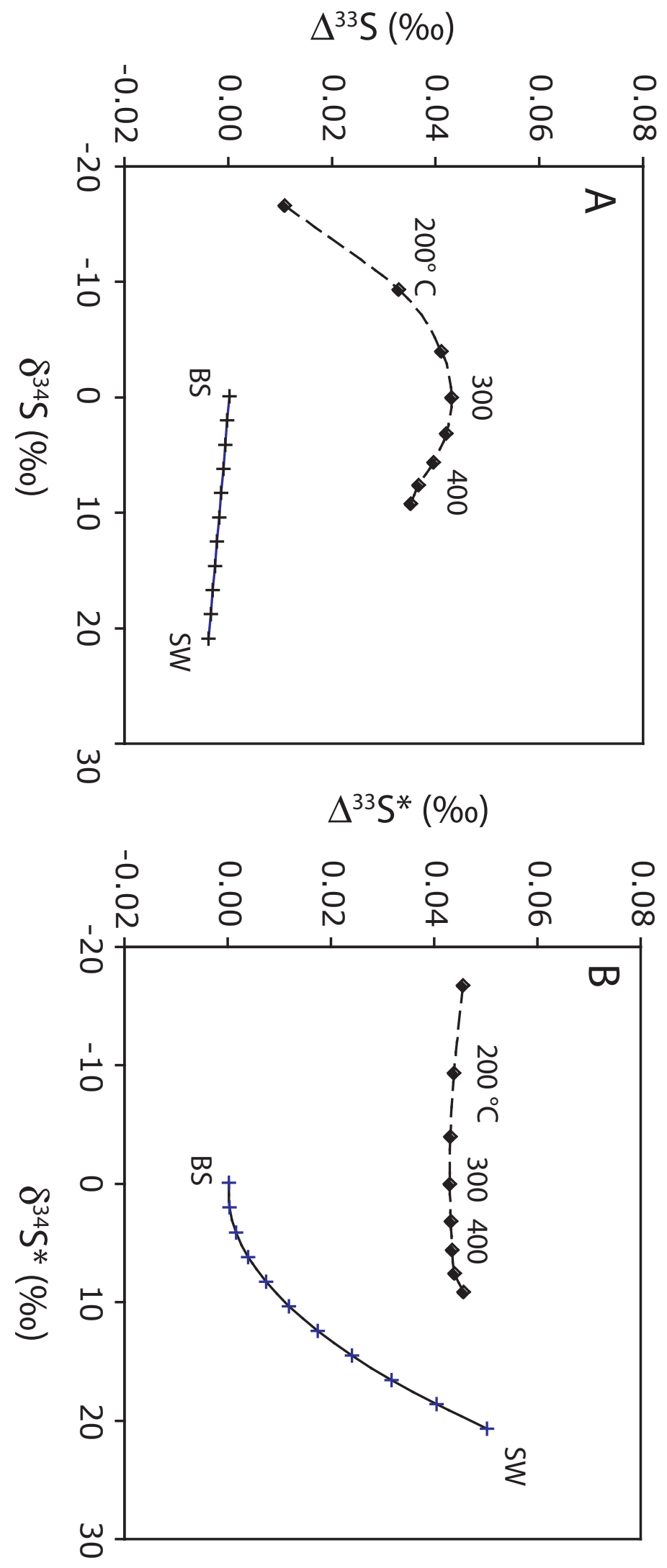


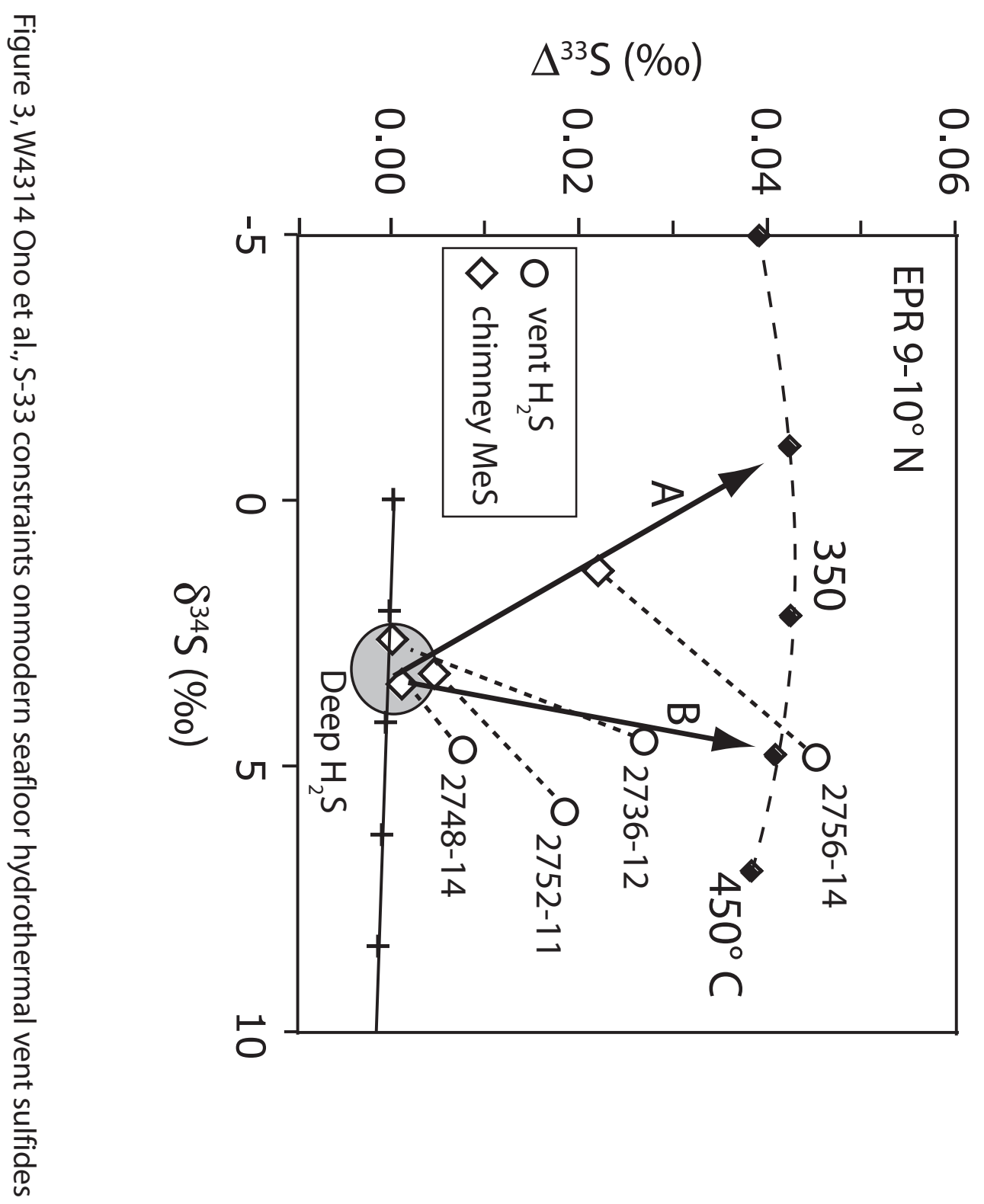


